\title{
Use of amaranth, quinoa and kañiwa in extruded corn-based snacks
}

\section{Ramos Diaz, Jose Martin}

2013-07

Ramos Diaz, J M , Kirjoranta , S , Tenitz , S , Penttilä , P A , Serimaa , R , Lampi , A-M \& Jouppila , K 2013, ' Use of amaranth, quinoa and kañiwa in extruded corn-based snacks ' , Journal of Cereal Science, vol. 58 , no. 1 , pp. 59-67 . https://doi.org/10.1016/j.jcs.2013.04.003

http://hdl.handle.net/10138/136426

https://doi.org/10.1016/j.jcs.2013.04.003

acceptedVersion

Downloaded from Helda, University of Helsinki institutional repository.

This is an electronic reprint of the original article.

This reprint may differ from the original in pagination and typographic detail.

Please cite the original version. 


\section{Accepted Manuscript}

Use of Amaranth, Quinoa and KaÂiwa in extruded corn-based snacks

Jose Martin Ramos Diaz, Satu Kirjoranta, Seppo Tenitz, Paavo A. Penttilu, Ritva Serimaa, Anna-Maija Lampi, Kirsi Jouppila

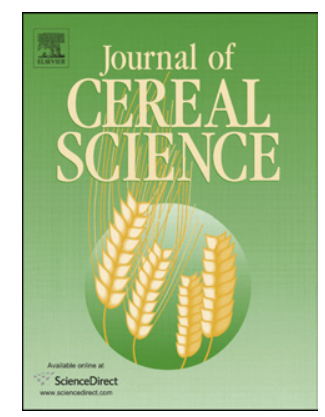

PII:

S0733-5210(13)00061-1

DOI:

10.1016/j.jcs.2013.04.003

Reference: $\quad$ YJCRS 1702

To appear in: Journal of Cereal Science

Received Date: 11 January 2013

Revised Date: 8 April 2013

Accepted Date: 12 April 2013

Please cite this article as: Ramos Diaz, J.M., Kirjoranta, S., Tenitz, S., Penttilu, P.A., Serimaa, R., Lampi, A.-M., Jouppila, K., Use of Amaranth, Quinoa and KaÂiwa in extruded corn-based snacks, Journal of Cereal Science (2013), doi: 10.1016/j.jcs.2013.04.003.

This is a PDF file of an unedited manuscript that has been accepted for publication. As a service to our customers we are providing this early version of the manuscript. The manuscript will undergo copyediting, typesetting, and review of the resulting proof before it is published in its final form. Please note that during the production process errors may be discovered which could affect the content, and all legal disclaimers that apply to the journal pertain. 


\section{Highlights}

- Greater expansion and lower hardness by adding tested flours (e.g. quinoa)

- Water content and screw speed had the greatest effect on expansion and hardness.

- Remarkable stability of lipids in whole extrudates exposed to HR humidity. 
1 USE OF AMARANTH, QUINOA AND KAÑIWA IN EXTRUDED CORN-BASED

2 SNACKS

3

4 Jose Martin Ramos Diaz ${ }^{*}$, Satu Kirjoranta ${ }^{1}$, Seppo Tenitz ${ }^{1}$, Paavo A. Penttilä ${ }^{2}$, Ritva

$5 \quad$ Serimaa $^{2}$, Anna-Maija Lampi $^{1}$, Kirsi Jouppila $^{1}$

$6{ }^{1}$ Department of Food and Environmental Sciences, P.O. Box 66 (Agnes Sjöbergin katu 2),

$7 \quad$ FI-00014 University of Helsinki, Finland.

$8 \quad{ }^{2}$ Department of Physics, P.O. Box 64 (Gustaf Hällströmin katu 2), FI-00014 University of

9 Helsinki, Finland.

$10{ }^{*}$ Corresponding author. Jose Martin Ramos Diaz, P.O. Box 66 (Agnes Sjöbergin katu 2), FI-

1100014 University of Helsinki, Finland. E mail address: jose.ramosdiaz@ helsinki.fi. Tel. +358

12 417100591. Fax. +358919158460.

13

14

1

\section{Keywords:}

Amaranth; quinoa; kañiwa; extrusion

\section{Abbreviations:}

SEI (sectional expansion index), WCE (water content of extrudates), WCM (water content of mass), RH (relative humidity), SS (screw speed), TEM (temperature of die)

2


27

28

29

\section{ABSTRACT}

Amaranth (Amaranthus caudatus), quinoa (Chenopodium quinoa) and kañiwa (Chenopodium pallidicaule) are pseudocereals regarded as good gluten-free sources of protein and fiber. A co-rotating twin screw extruder was used to obtain corn-based extrudates containing amaranth/quinoa/kañiwa (20\% of solids). Box-Behnken experimental design with three independent variables was used: water content of mass (WCM, 15-19\%), screw speed (SS, 200-500 rpm) and temperature of the die (TEM, 150-170 $\left.{ }^{\circ} \mathrm{C}\right)$. Milled and whole samples were stored in open headspace vials at 11 and $76 \%$ relative humidity $(\mathrm{RH})$ for a week before being sealed and stored for 9 weeks in the dark. Hexanal content was determined by using headspace gas chromatography. Extrudates containing amaranth presented the highest sectional expansion index $(\mathrm{SEI})(\mathrm{p}<0.01)$ while pure corn extrudates (control) presented the lowest SEI and greatest hardness ( $\mathrm{p}<0.01)$. SEI increased with increasing SS and decreasing WCM. In storage, whole extrudates exposed to $76 \% \mathrm{RH}$ presented the lowest formation of hexanal. This study proved that it was possible to increase SEI by adding amaranth, quinoa and kañiwa to pure corn flour. The evaluation of lipid oxidation suggested a remarkable stability of whole extrudates after exposure to high RH. 
50

51

52

53

54

\section{INTRODUCTION}

Amaranth, quinoa and kañiwa are pseudocereals that have been cultivated in South America for more than 5000 years. These climate resilient crops were important sources of protein, fiber and fat during pre-Hispanic times. At present, their potential as gluten-free cereal substitute is starting to attract industrial and scientific attention (Gallagher et al., 2004).

Interest in gluten-free products has increased in the developed world; this encompasses the increasing necessity for alternatives with added nutritional value thereby providing consumers with high quality protein, lipid, fiber and bioactive compounds. Repo-Carrasco et al. (2003) reported that quinoa var. Amarilla de Marangani had no limiting amino acids. In fact, Ranhotra et al. (1993) observed that the quality of protein in quinoa (protein digestibility, protein efficiency ratio and nitrogen balance) is equivalent to that of milk protein casein.

Scientific studies also suggested that kañiwa and amaranth had protein content and amino acid composition comparable to quinoa as reviewed in Repo-Carrasco (2011). Amaranth, quinoa and kañiwa are also particularly rich in polyunsaturated fatty acids. Sinopoulos (2001) suggested that a high linoleic:linolenic acid ratio (14:1-20:1), which is the case in western countries, could promote the pathogenesis of degenerative diseases (e.g., cancer and osteoporosis). In that sense, linoleic:linolenic acid ratio in quinoa falls within the recommended values $(5: 1-10: 1)$. When it comes to other bioactive compounds, quinoa and kañiwa are important sources of flavonoids (mainly glycosides of the flavonols kaempferol and quercetin). Kañiwa is especially rich in resorcinols which are not common compounds in plants. In fact, cereal alkylresorcinols were suggested to have an active role in the prevention of cancer and microbial infections (Ross et al., 2003). On the other hand, there is remarkable variation in the content of dietary fiber in pseudocereals mainly due to environmental 
conditions. In general, soluble dietary fiber is lower than insoluble dietary fiber in amaranth, quinoa and kañiwa (approximately 1:5) (Repo-Carrasco, 2011). Despite their nutritional advantages, there is a lack of interest for their consumption due to socio-economic factors in Latin America.

The first step towards the industrialization of pseudocereals has been through the adoption of low cost technological processes such as extrusion cooking which is characterised by its capacity of increasing the digestibility of starch and protein. However, the effect of extrusion cooking on micronutrients and bioactive compounds is still a matter of scientific investigation.

The potential of these pseudocereals as extrusion ingredients for the production of snack foods, baby foods and breakfast cereals has been recognised by Ding et al. (2005), Mauser and van Lengerich (1992), and Repo-Carrasco (2011).

Essentially, the extrusion of starchy food provokes gelatinization of starch, denaturation of protein and formation of starch-lipid and protein-lipid complexes (Ho and Izzo, 1992;

Mercier et al., 1980). The lipid interaction with carbohydrates and proteins (or both) might occur on a physical (entrapment) or molecular level. In fact, Ho and Izzo (1992) hypothesised that if lipids were simply entrapped within a corn-flour matrix, there should be minimal variation in the enzymatic extractability of different lipids. On the other hand, molecularlevel interactions would present different mechanisms, and lead to different enzymatic extractability, depending on the type of lipid (e.g., chain length of fatty acid and polarity) and bonding. During extrusion, the presence of fatty acids and amylose can lead to the formation of complexes that may result in decreasing expansion ratios (Bhatnagar and Hanna, 1994). Lue et al. (1991) observed that the addition of dietary fiber (30\% of solids) to corn flour caused lower expansion and greater hardness than those of the control material. 
101 Even though the mechanisms of lipid oxidation in bulk oil have been investigated for many

102

103

104 years, information on lipid oxidation in solid matrices remains limited. Depending on the type of interaction between amylose and fatty acids in solid matrices (such as extrudates), lipid oxidation may lead to the formation of volatile compounds during storage (Gray et al., 2008; Naknean and Meenune, 2010). Nelson and Labuza (1994) affirmed that the physical state of a food matrix can play an important role in lipid oxidation kinetics. For instance, low rate of hexanal production in starch-based solid matrices might be due to small free volume within a glassy matrix, thereby reducing the ability of oxygen to diffuse towards lipids, and hexanal to diffuse out of the matrix (Parker et al., 2002).

The aims of the present research were to prepare gluten-free corn-based extrudates containing quinoa, amaranth and kañiwa, study the effects of extrusion process variables on the physical properties of the extrudates and evaluate lipid stability after exposure to different humidity conditions. This study proposes novel alternatives for the production and diversification of gluten-free products with added nutritional value by using a low energy technology.

(1)

(1)


125

126

127

128

129

130

131

132

133

134

135

136

137

138

139

140

141

142

143

144

145

146

147

148

149

2

143

144

\section{MATERIALS AND METHODS}

\subsection{Materials}

Amaranth (Amaranthus caudatus var. Oscar blanco) was obtained from the province of

Carhuaz in Northern Peru, quinoa (Chenopodium quinoa var. Rosada de Huancayo) from the province of Jauja in the Centre of Peru and kañiwa (Chenopodium pallidicaule var. Cupi) from the region of Puno in Southern Peru. Samples were supplied by the Andean cereal program at the National Agrarian University 'La Molina' (UNALM, Peru). The grains were cleaned and milled (500 $\mu \mathrm{m}$ mesh size) prior to vacuum packing and delivery to Finland.

Corn flour, supplied by Limagrain (France), had a mean particle size of about $150 \mu \mathrm{m}$ and it was gluten-free since it contained less than $20 \mathrm{ppm}$ of gluten (EU legislation). The corn flour was mixed with quinoa/amaranth/kañiwa (tested flours) at a ratio of 80:20 (of solids). The chemical analysis of raw materials was conducted in triplicate and detailed results are presented in Appendix A. Considerable differences in dietary fiber were observed among amaranth, quinoa and kañiwa $(8.6 \%, 11.5 \%$ and $20.5 \%$ of solids, respectively).

(1)

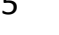


150

151

152

153

154

155

156

157

158

159

160

161

162

163

164

165

166

167

168

169

170

171

172

173

174

\subsection{Extrusion}

The extrusion was carried out in a twin-screw laboratory extruder (Thermo Prism PTW24

Thermo Haake, Polylab System, Germany). The extruder consisted of seven sections (96 mm each) with individual temperature control in six of them; these sections were electrically heated and cooled by water. The total length of the screw was $672 \mathrm{~mm}$ and consisted of six conveying screws $(144,49,47,95,72$ and $53 \mathrm{~mm})$, six mixing areas $(26,30,30,30,35$ and $25 \mathrm{~mm}$ ) and an extrusion screw element $(36 \mathrm{~mm})$; the first mixing area was skipped on feeding. The feed rate ( $84 \mathrm{~g} / \mathrm{min})$, screw speed (SS), water content of mass $^{1}(\mathrm{WCM})$ and temperature profile were fixed based on preliminary experiments; water was added into the mass using a peristaltic pump. The section 1 was set at $40^{\circ} \mathrm{C}$, the sections 2 and 3 at $70{ }^{\circ} \mathrm{C}$, the sections 4,5 and 6 at $110{ }^{\circ} \mathrm{C}$ and the temperature of the die (TEM) was either 150,160 or $170{ }^{\circ} \mathrm{C}$. Box-Behnken experimental design with three independent variables was used: WCM (15 17 and 19\%), SS (200, 350 and $500 \mathrm{rpm})$ and TEM (150, 160 and $\left.170{ }^{\circ} \mathrm{C}\right)($ See Appendix B). Values of torque and pressure at die were recorded during the extrusion process as a function of time, and their average values were calculated using the data collected during the sample collection.

67

68

69




\subsection{Determination of physical properties}

177

178 The diameter of twenty specimens was measured using a vernier caliper. Sectional expansion 179 index (SEI) was calculated as the ratio between the cross sectional area of the extrudate and 180 the area of the die.

Hardness of the extrudates was measured as the slope of force-distance curve $\left(\mathrm{N} \mathrm{mm}^{-1}\right)$ when compression was perpendicularly enforced under three point bending. A universal testing machine (Instron 4465, Instron Ltd., High Wycombe, UK) was fitted with a flat rectangularshaped aluminium probe, $3 \mathrm{~mm} \times 29 \mathrm{~mm}$. Samples were placed perpendicularly over a sample holder (distance between two holding points was $12 \mathrm{~mm}$ ). The speed of the aluminium cross head was $5 \mathrm{~mm} / \mathrm{min}$. Five randomly collected samples from each experiment were vacuum dried at $54{ }^{\circ} \mathrm{C}$ for 72 hours before hardness measurement. This procedure was followed in order to prevent the plasticising effect of water on hardness and, therefore, obtain comparable results. Sizes of all samples were 100-mm in length with weight loss in drying (vacuum drying at $54{ }^{\circ} \mathrm{C}$ for 72 hours). 


\subsection{Analysis of large scale structures}

202

203 Samples for stereomicroscopy inspection were obtained from experiment 2 (WCM 15\%, SS

$500 \mathrm{rpm}$, TEM $160^{\circ} \mathrm{C}$ ). Samples were cut in pieces of $15 \mathrm{~mm}$ by using a small scale electric saw. A Zeiss Steni 2000 Binocular Stereo Microscope (Wetzlar, Germany) equipped with an

AxioCam digital camera was used in the inspection. For images at longer distance, an olympus Zuiko objective (9-18 mm f/4.0-5.6 Lens for Olympus; Tokyo, Japan) was used. Images were processed using Axiovision 3.1 software (Carl Zeiss, Thornwood, NY).

209

\subsection{Analysis of nanostructures}

Milled extrudates from experiment 2 were pressed into metal rings of a thickness of $1 \mathrm{~mm}$ and covered with Mylar foil. Wide- and small-angle x-ray scattering (WAXS and SAXS) 
222 One set of samples was milled using an ultra-centrifugal mill (Retsch ZM 200, Haan,

223 Germany) at $12000 \mathrm{rpm}$ in order to reach a mean particle size of about $500 \mu \mathrm{m}$, while a

224

225

226

227

228

229

230

231

232

233

234

235

236

237

238

239

240

241

242

243

244

245

second set of samples was cut into pieces of $15 \mathrm{~mm}$ in length (whole extrudates). Milled and

whole extrudates were divided and placed into separate 20-ml headspace vials so there was: 2

$\mathrm{g}$ of milled extrudate / $0.5 \mathrm{~g}$ of whole extrudate. Due to the low density of whole extrudates,

standardizing the mass of milled and whole extrudates was not possible. Open vials

containing the samples were stored in vacuum desiccators at 11 and $76 \%$ relative humidity

(RH) at $20{ }^{\circ} \mathrm{C}$ for one week (exposure time) before being sealed and stored for 0, 2, 5 and 9

weeks at room temperature in the dark.

Hexanal content was analysed using static headspace gas chromatography (HS-GC). The

Autosystem XL gas chromatograph was equipped with an HS40XL head space sampler

(Perkin-Elmer, Shelton, CT; column NB 54, Nordion). The injection and detection

temperature was $250{ }^{\circ} \mathrm{C}$. Flame gases were synthetic air and hydrogen, and carrier gas was

helium. The column had a length and inner diameter of $25 \mathrm{~m}$ and $320 \mu \mathrm{m}$, respectively. Vials

were thermostated at $80{ }^{\circ} \mathrm{C}$ for 18 min prior to injection. The run temperature was $60{ }^{\circ} \mathrm{C}$ and

the run time 10 min per sample. An external standard curve was plotted using a solution of

hexanal in isopropanol $\left(10^{7} \mathrm{ng}\right.$ hexanal/l). This solution was added to open vials containing

pure corn extrudates $(4,6,8,10,12,32,42,52,72 \mu \mathrm{l}$ hexanal solution/vial). The vials were

stored in a shaking incubator overnight (12 hours) before GC analysis. The standard curves

were plotted for milled and whole extrudates (See Appendix C1 and C2).

\subsection{Statistical analysis}


246 The Box-Behnken experimental design with three independent variables comprised 15

247 experiments that were done following the increasing temperature of die for practical reasons

248 (See Appendix B). Partial least squares (PLS) regression analysis was used to study the

249 effects of independent variables on response variables (Simca P7.01, Umetrics AB, Sweden).

250 PLS weight plots were used to identify the most important directions of variability of

251 different samples in a multivariate data matrix. Chemical analyses were conducted in

252 triplicate and the results expressed as means and standard deviation (SD). The processing

253 conditions in experiment 2 led to high extrudate expansion. Therefore, the data obtained from

254 that experiment were statistically analysed by analysis of variance (ANOVA), and by

255 computing Least Significant Difference ( $p<0.01 ; \mathrm{p}<0.05)$ (v17.0 SPSS Inc., Chicago, Illinois).

256

257

3. RESULTS AND DISCUSSION

258

259

3.1. Effect of independent extrusion variables on response variables

260

261

\subsubsection{Torque and pressure at die}

262

263 Pressure (15.5-97.4 bar) and torque increased (28.3-44.4 Nm) as WCM and SS decreased.

264 Results also suggested that the values of torque and pressure were strongly correlated as they

265 were located on the upper right hand quarter of the PLS weight plot (Figure 1). Indeed,

266 WCM and SS were the most influential independent variables, followed distantly by TEM

267 (VIP value, Table 1). In Figure 1, torque and pressure were located on the opposite side of

268 WCM and SS, indicating strong negative correlation. This partly agrees with the results

269 obtained by Ilo and Liu (1999) in which blends of rice and amaranth flour (20, 40 and 60\% of

270 amaranth flour) underwent extrusion in a twin-screw extruder. They claimed that torque and 
271 pressure decreased as water content of feed and SS increased. Also, Martinelli et al. (1983)

272 observed that an increase in SS decreases the length of filled flights, thereby reducing torque

273 and pressure. It seems that the addition of $20 \%$ amaranth/quinoa/kañiwa in corn flour

274 (resulting in higher fat and fiber content) had some effect on the viscosity of the mass

275 resulting in considerable changes of torque and pressure.

276

277 The predicting and descriptive abilities of the PLS model for torque and pressure were in

278 general good, which appears in high values of prediction coefficient $\left(Q^{2}\right)$ and coefficient of

279 determination $\left(\mathrm{R}^{2}\right)$ (Table 1$)$. The model of torque for extrudates containing amaranth

280 presented the lowest $\mathrm{Q}^{2}(0.17)$.

281

282

\subsubsection{Expansion}

283

In the PLS weight plot (Figure 1), values of SEI were located on the lower right hand quarter and showed negative correlation with WCM and positive correlation with SS. ChavezJauregui et al. (2000) and Coulter and Lorenz (1991) found that SEI increases at higher SS for corn-based extrudates containing quinoa and defatted amaranth flour, respectively. It was noticed that as fiber content increased, SEI became increasingly correlated with SS and less correlated with WCM (Figure 1). In terms of expansion, flour mixtures containing more fiber seemed less sensitive to changes in water content and increasingly sensitive to changes in SS.

291 This trend was also noticeable by comparing contour plots (Figure 2); while SS had minor effect on SEI for extrudates containing pure corn, amaranth and quinoa, small changes in SS caused considerable changes in SEI for extrudates containing kañiwa. 
295 The predicting and descriptive abilities of the PLS model for SEI were in general acceptable,

296 taking into consideration that the $\mathrm{Q}^{2}$ was between 0.2 and 0.8 , and $\mathrm{R}^{2}$ was generally above

297 0.6. The PLS model for extrudates containing pure corn possessed the lowest $\mathrm{Q}^{2}(0.2)$ and $\mathrm{R}^{2}$ $298(0.65)$

299

300

\subsubsection{Hardness}

301

302 Low hardness was associated with low WCM and high SS. In fact, the PLS weight plot 303 showed a high positive correlation with WCM and negative correlation with SS. It was noticed that as fiber content increased, hardness became increasingly correlated with SS and between SEI and hardness in their studies conducted on amaranth and rice.

310 changes in WCM.

A comparison of the contour plots (Figure 2) indicated that changes in hardness were more associated with SS rather than with WCM for extrudates containing kañiwa. Instead, hardness in extrudates containing amaranth, quinoa and pure corn appeared more associated with

317

WCE increased as WCM increased and SS decreased; the effect of temperature on WCE was 319 negligible as appears in the PLS weight plot (Figure 1). WCE and hardness were heavily 
320 located on the upper left quarter of the PLS weight plot which indicates a strong positive

321

322

323

324

325

326

327

328

329

330

331

332

333 correlation between them.

In this case, the predicting abilities of the PLS model were considerable, which appear in the low root mean square error of prediction (RMSEP) and moderately high $\mathrm{Q}^{2}$ (except for pure corn extrudates, Table 1). The descriptive abilities of this model, represented by $\mathrm{R}^{2}$, were between 0.4 and 0.9 .

\subsection{Characterization of the most expanded extrudates}

\subsubsection{Comparison of SEI and hardness}

Extrudates obtained from experiment $2\left(\mathrm{WCM} 15 \%\right.$, SS $500 \mathrm{rpm}$, TEM $\left.160{ }^{\circ} \mathrm{C}\right)$ presented the highest SEIs (except for pure corn extrudates) and lowest hardness when compared to extrudates from other experiments. Therefore, this and the follow-up sections refer to samples obtained under these specific conditions (experiment 2) unless otherwise specified.

Extrudates containing amaranth, quinoa and kañiwa presented SEIs of 7.6, 6.1 and 5.1, respectively while pure corn extrudates presented a SEI of 4.4; differences in SEIs were significant among samples $(\mathrm{p}<0.01)$ and, especially, compared to pure corn extrudates $(\mathrm{p}<0.001)$. The higher SEIs of extrudates containing amaranth/quinoa/kañiwa may be attributed to the higher plasticising effect of monosaccharides, oligosaccharides, amines and water (See Appendix A) present in the mass (De Graaf et al., 2003). Plasticisers tend to space out molecules and reduce interaction leading to less brittle polymeric structures and greater swelling capacities (De Graaf et al., 2003; Krog, 1973). It is possible that pure corn 
extrudates reached the lowest SEI due to the low content of plasticisers. Interestingly, pure corn extrudates reached higher SEI (5.1) in experiment 3 where SS (350 rpm) and TEM (150

$\left.{ }^{\circ} \mathrm{C}\right)$ were lower. This not only agrees with the logic that plasticisers might cause greater expansion but also suggests that the effect of independent variables on SEI may vary widely depending on the compositional characteristics of the raw material (Figure 1).

Except for pure corn, extrudates with higher contents of dietary fiber (kañiwa>quinoa>amaranth) presented lower SEIs. From these results, it is believable that dietary fiber caused disruption of internal structures leading to progressive reduction of SEIs. This logic agrees with the observations of Onwulata et al. (2001) who claimed that increasing fiber content in corn flour decreased SEI and increased bulk density.

Extrudates containing kañiwa presented the lowest hardness $\left(28 \mathrm{~N} \mathrm{~mm}^{-1}\right)$, while extrudates containing quinoa and amaranth presented hardness values of 39 and $53 \mathrm{~N} \mathrm{~mm}^{-1}$, respectively. Pure corn extrudates showed the highest hardness value $\left(89 \mathrm{~N} \mathrm{~mm}^{-1}\right)$. Hardness was significantly higher $(\mathrm{p}<0.01)$ in pure corn extrudates than in extrudates containing amaranth/quinoa/kañiwa.

While the plasticising effect of monosaccharides, oligosaccharides, amines and water may reduce attractive forces between polymers (e.g., polysaccharides) leading to hardness reduction (De Graaf et al., 2003), lipids might also associate with amylose leading to the formation of complexes and, therefore, increasing the stiffness of polymeric structures (Bhatnagas et al., 1994; Mercier et al., 1980). Mercier et al. (1980) found evidence that amylose-lipid complexation increased hardness as a result of extrusion cooking (manioc starch). Contrasting, though, both explanations are logical in the present context since 
370 physical characteristics, such as hardness, are the result of the interaction of biocomponents

371 (e.g., starch and protein) at a physical and/or molecular level. It is probable that, by adding

372 amaranth, quinoa and kañiwa (20\% of solids), plasticizers somehow disrupted polymeric

373 structures, thereby reducing hardness compared to pure corn extrudates. Although the

374 mechanisms leading to hardness reduction are not clear in the present study, it is also

375 suggested that the nucleation capacity of fiber limited the compactness of the structure with

376 possible implications on hardness. From this, it can be deduced that there was limited chain-

377 to-chain interactions between polysaccharides (and proteins) during the extrusion of blends

378 (amaranth/quinoa/kañiwa 20\% of solids) leading to progressive hardness reduction

379 (kañiwa<quinoa<amaranth).

380

\subsubsection{Large scale structures}

382

383

Extrudates containing amaranth and quinoa presented well-defined pores of different sizes with semi-flat sides. In contrast, extrudates containing kañiwa presented small, irregular and poorly defined pores. Pure corn extrudates had a rigid structure with bigger pores and thicker walls than other samples (Figure 3). It is plausible that fiber present in kañiwa caused severe bubble disruption leading to lower radial expansion and higher number of pores. Amaranth and quinoa, on the other hand, had lower content of dietary fiber which could limit bubble disruption.

Despite their low radial expansion compared to fibre-free corn extrudates, Lue et al. (1991) observed that extrudates containing higher concentrations of fiber (10, 20 and $30 \%$ of solids), at different particle sizes (10, 40, 120 and 200 mesh), had more air cells. Finer ground fiber (10 mesh) had greater water holding capacity leading to more nucleation sites for water 
395

396

397

398

399

400

401

402

403

404

405

406

407

408

409

410

411

412

413

414

415

416

417

418

419

vapour to develop as the mass was expelled through the die (Lue et al., 1991). This seems to agree with the results obtained in the present study.

Visual difference could not be observed between extrudates containing amaranth and quinoa in terms of pore size distribution. Both extrudates suffered similar damage under enforced physical modification (See Appendix D). Extrudates containing kañiwa exhibited a clear cut surface whereas pure corn extrudates suffered severe structural damages during cutting. This type of damage could correspond to brittleness break (breakage with minimum deformation) and, therefore, be linked to the lack of plasticisers in the raw material. As stated by De Graaf et al. (2003), the presence of a homogenously blended plasticiser such as water, sugars and amines may prevent the formation of brittle (and hard) starch-based extrudates.

Colour differences were strongly associated with the particular composition of each blend (Figure 3E). Extrudates containing amaranth and quinoa maintained a light colour while kañiwa conferred a dark colour to extrudates. Crude fiber (small brown spots) was noticeable particularly in extrudates containing kañiwa (Figure 3C, E). Pure corn extrudates, though, had a yellowish translucent structure.

\subsubsection{Nanostructures}

The nanoscale structure of the milled extrudates from experiment 2 was studied with WAXS and SAXS. The obtained WAXS intensities (Figure 4) displayed peaks characteristic of the processing-induced $V_{h}$ and $E_{h}$ crystal structures, which are forms of amylose-lipid helical complexes typically obtained in extrusion (Mercier et al., 1980; Penttilä et al., 2011). Based

on visual comparison of the heights of the diffraction peaks, the $\mathrm{V}_{\mathrm{h}}$ structure (peaks at $2 \theta=7.4^{\circ}, 12.9^{\circ}$, and $19.6^{\circ}$ ) dominated in all samples, whereas the proportion of the $\mathrm{E}_{\mathrm{h}}$ 
420 structure (peaks at $2 \theta=6.9^{\circ}, 11.9^{\circ}$, and $18.2^{\circ}$ ) was highest in the pure corn sample and lowest

421 in the sample containing 20\% kañiwa. The SAXS intensities (inset in Figure 4) obeyed

422 power laws with an exponent around $-3.5( \pm 0.2)$ and no peak or shoulder from lamellar

423 repeating structures in the studied length scale $(2-30 \mathrm{~nm})$ was observed. Combined with the

424 WAXS results, this result indicates that the extrudates from experiment 2 contained sheets of

425 crystallized amylose-lipid complexes without the formation of ordered stacks.

\subsubsection{Formation of hexanal during storage}

The hexanal formation in milled extrudates was comparatively higher than in the whole extrudates (except for whole extrudates containing quinoa and exposed to $11 \% \mathrm{RH}$ ). There was a tendency towards lipid oxidation in extrudates containing quinoa and kañiwa, exposed to $11 \% \mathrm{RH}$. The lipid stability of extrudates containing either amaranth or only pure corn, though, appeared to be unaffected by humidity exposure and physical modification (Figure

5). Exposure to different RH (11\% and 76\%) may have caused sharp differences in lipid oxidation due to hydration of catalysers or hydrogen binding of radicals (Labuza et al., 1972). As a matter of fact, density and wall thickness of extrudates might have some effect on the mobility of fatty acids and their interaction with amylose, oxygen and water molecules. In general, the denser the extrudate and the thicker its walls, the less lipids tend to oxidise (Gray et al., 2008; Kim and Maga, 1994).

441 For milled extrudates containing kañiwa and exposed to $11 \% \mathrm{RH}$, the hexanal content 442 increased 25 times during storage whereas, for the ones exposed to $76 \% \mathrm{RH}$, the hexanal content increased only 3 times (Figure 5). Therefore, differences in trends of hexanal production were considerable in milled extrudates containing kañiwa. In contrast, the trends 
445 of hexanal production corresponding to milled extrudates containing amaranth and quinoa, and pure corn showed no major differences (11\% and 76\% RH).

Mercier et al. (1980) reported that the formation of amylose-lipid complexes could take place during the gelatinization and cooling of starch-based materials. Less common but still likely, amylopectin and lipids may form complexes depending on the source of amylopectin; Huang and White (1993) found that modified waxy corn starches are likely to associate with lipids and form complexes. In view of this, the chosen processing conditions and raw material used in this study were probably suitable for the formation of amylose-lipid complexes. In fact, $\mathrm{x}$ ray diffraction analysis suggested the presence of $E_{h}$ and $V_{h}$ crystal forms (WAXS) in milled samples containing amaranth, quinoa, kañiwa and pure corn, without evidence of stacking (SAXS). Obiro et al. (2012) suggested a model in which amylose-lipid complexes are organised in lamellae interspersed in amorphous regions; this model may resemble ours given the SAXS results obtained.

Naknean and Meenune (2010) suggested that the formation of amylose-lipid complexes could be reversible. This would mean that, depending on the physicochemical characteristics of the sample such as viscosity and molecular mobility, there could be some release of fatty acids and other compounds that might become a target of oxidation. In this sense, it was difficult to understand why milled extrudates containing amaranth, quinoa and especially pure corn had a low, steady and indistinct production of hexanal, despite changes in humidity exposure. On the other hand, the curves of hexanal production for milled extrudates containing kañiwa at

467 different RH (11 and 76\%) suggested a more active role of initiators (cations) and higher interaction between oxygen and fatty acids. Extrudates containing kañiwa had the highest content of ash and this might have affected the rate of hexanal production during storage 
470 compared to other samples. Labuza et al. (1980) found that dilution of transition metal 471 cations hinders lipid oxidation above $0.7 \mathrm{a}_{\mathrm{w}}$.

472 The trends of hexanal production between whole extrudates containing quinoa and kañiwa

473 (11 and 76\% RH) were considerably different from one another (Figure 5A, B). There was a

474200 -fold increase in hexanal content for extrudates containing quinoa and exposed to $11 \%$

475 RH (inset in Figure 5A). These results were unexpected, considering the exceptionally lower 476 hexanal production of the rest of the samples. Whole extrudates containing kañiwa exhibited 477 a 15 fold increase in hexanal content after 9 week storage. In contrast, whole extrudates exposed to $76 \%$ RH showed no significant difference $(\mathrm{p}<0.01)$ in their hexanal content

479 during storage. It was also observed that extrudates containing amaranth and pure corn (11 480 and $76 \% \mathrm{RH}$ ) had a high degree of stability in storage, independent of humidity exposure and 481 physical modification. This suggests that lipids might have interacted with starch and/or 482 protein at a molecular (e.g., complexation) and physical level (e.g., entrapment).

484 Even though lipids were likely to be involved in complex formation, the observations made during lipid oxidation tests suggested that lipids, present in extrudates with higher fiber content (and lower hardness), were more prone to oxidation. Unlike extrudates containing amaranth, extrudates containing quinoa and kañiwa showed a marked increase in hexanal production during 9 weeks (storage after exposure to $11 \% \mathrm{RH}$ ). This means that plasticisers (and possibly fiber) might have limited chain to chain interaction, thereby reducing the capacity of macromolecules (e.g., amylose and amylopectin) to form a protective 'coat' around lipids (entrapment). 
This study showed that it was possible to prepare expanded gluten-free corn-based extrudates containing amaranth, quinoa and kañiwa flour (20\% of solids). The SEI was the highest in extrudates containing amaranth and the lowest in pure corn extrudates. Decreasing WCM had probably the greatest effect on extrudates by increasing SEI and decreasing hardness. The increasing contents of dietary fiber (amaranth<quinoa<kañiwa) were proposed to cause the decrease of SEI and hardness.

The hexanal formation was considerably higher in milled samples than in the whole extrudates (exposed to either 11 or $76 \%$ RH prior to storage), except for extrudates containing quinoa. The evaluation of lipid oxidation during storage suggested a remarkable stability of fat in whole extrudates after exposure to high RH. Further investigation on the effect of water plasticization on the oxidative stability of starchcomplexed lipids would be highly desirable. 
5. ACKNOWLEDGEMENTS

523

524 We wish to thank Mrs Orfelina Chuquipiondo, Lic. Listail Diaz and Dr. Luz Gomez (head of

525 the Andean cereal project at National Agrarian University in Lima, Peru) for providing the

526 raw material used in the present study. Mr. Enrique Torres (General Manager of Jarcon del

527 Peru S.A.) is also thanked for arranging the cleaning, milling and packing of the raw material.

528 Technician Timo Holopainen from University of Helsinki is thanked for technical help during 529 extrusion.

530

531

532

533

534

535

536

537

538

539

540

541

542

543

544

545

546

547 


\section{REFERENCES}

550

551 Bhatnagar, S., Hanna, M.A., 1994. Amylose-lipid complex formation during single-screw 552 extrusion of various corn starches. Cereal Chemistry 71, 582-587.

553

554

Chavez-Jauregui, R.N., Silva, M.E.M.P., Areas, J.A.G., 2000. Extrusion cooking process for amaranth (Amaranthus caudatus L.). Journal of Food Science 65, 1009-1015.

556

557

Coulter, L.A., Lorenz, K., 1991. Extruded corn grits - quinoa blends: II. Physical

characteristics of extruded products. Journal of Food Processing and Preservation 15, 231-

559 259.

560

De Graaf, R.A., Karman, A.P., Janssen, L.P.B.M., 2003. Material properties and glass transition temperatures of different thermoplastic starches after extrusion processing. Starch $55,80-86$.

564

Ding, Q.-B., Ainsworth, P., Tucker, G., Marson, H., 2005. The effect of extrusion conditions on the physicochemical properties and sensory characteristics of rice-based expanded snacks. Journal of Food Engineering 66, 283-289.

Gallagher, E., Gormley, T.R., Arendt, E.K., 2004. Recent advances in the formulation of 570 gluten-free cereal-based products. Trends in Food Science and Technology 15, 143-142. 
572 Gray, D.A., Bowen, S.E., Farhat, I., Hill, S.E., 2008. Lipid oxidation in glassy and rubbery-

573 state starch extrudates. Food Chemistry 106, 227-234.

574

575 Ho, C.T., Izzo, M.T., 1992. Lipid-protein and lipid-carbohydrate interactions during

576 extrusion. In: Kokini, J.L., Ho, C.T., Karwe, M.V. (Eds), Food Extrusion Science and

577 Technology. Marcel Dekker, New York, pp. 415-426.

578

579 Huang, J.J., White, P.J., 1993. Waxy corn starch: monoglyceride interaction in a model

580

system. Cereal Chemistry 70, 42-47.

581

582

583

Ilo, S.E., Liu, Y., 1999. Extrusion cooking of rice flour and amaranth blends. LebensmittelWissenschaft und-Technologie 32, 79-88.

584

585

586

Kim, C.H., Maga, J.A., 1994. Chain length and functional group impact on retention during extrusion. In: Parliament, T.H., Morello, M.J., McGorrin, R.J. (Eds), Thermally Generated

Flavours: Maillard, Microwave and Extrusion Processes. American Chemical Society

588

Symposium Series 543, Washington, DC., pp. 105-153.

589

590

591

Krog, N. 1973. Influence of food emulsifiers on pasting temperature and viscosity of various starches. Starch 25, 22-27.

592

593

Labuza, T. P. 1980. The effect of water activity on reaction kinetics of food deterioration.

594 Food Technology 34, 36-41.

595 
596

597

598

599

600

601

602

603

604

605

606

607

608

609

610

611

612

613

614

615

616

617 Nelson, K.A., Labuza, T.P., 1994. Water activity and food polymer science: Implications of

618

619

620

Labuza, T.P., McNally, L., Gallagher, D., Hawkes, J., Hurtado, F., 1972. Stability of intermediate moisture foods. 1. Lipid oxidation. Journal of Food Science 37, 154-159.

Lue, S., Hsieh, F., Huff, H.E., 1991. Extrusion cooking of corn meal and sugar beet fiber:

effects on expansion properties, starch gelatinization and dietary fiber content. Cereal

Chemistry 68, 227-234.

Martinelli, F.G., 1983. Twin-Screw extruders: A Basic Understanding. Van Nostrand

Reinhold: New York, pp. 80-85.

Mauser, F., van Lengerich, B., 1992. System analytical model for the extrusion of starches. In:

Kokini, J.L., Ho, C., Karwe, M.V. (Eds.), Food Extrusion Science and Technology. Marcel

Dekker Inc., New York, pp. 619-630.

Mercier, C., Charbonniere, R., Grebaut, J., de la Gueriviere, J.F., 1980. Formation of amylose-lipid complexes by twin-screw extrusion cooking of manioc starch. Cereal

Chemistry 57, 4-9.

Naknean, P., Meenune, M., 2010. Factors affecting retention and release of flavor compounds in food carbohydrates. International Food Research Journal 17, 23-34.

state on Arrhenius and WLF models in predicting shelf life. Journal of Food Engineering 22, 271-289. 
621 Obiro, W.C., Ray, S.S., Emmambux, M.N., 2012. V-amylose Structural characteristics,

622 methods of preparation, significance, and potential applications. Food Reviews International $62328,412-438$.

624

625

Onwulata, C.I., Konstance, R.P., Smith, P.W., Holsinger, V.H., 2001. Co-extrusion of dietary 627

Parker, R., Gunning, Y.M., Lalloue, B., Noel, T.R., Ring, S.G., 2002. Glassy state dynamics, 629 its significance for biostabilisation and the role of carbohydrates. In: Levine H. (Ed.),

630

631 Amorphous Food and Pharmaceutical Systems. The Royal Society of Chemistry, Cambridge, pp. 73-87.

632

Penttilä, P.A., Suuronen, J.-P., Kirjoranta, S., Peura, M., Jouppila, K., Tenkanen, M., Serimaa, 634 R., 2011. X-ray characterization of starch-based solid foams. Journal of Materials Science 46, 635 $3470-3479$.

636

637

Ranhotra, G.S., Gelroth, J.A., Glaser, B.K., Lorenz, K.J., Johnson, D.L., 1993. Composition and protein nutritional quality of quinoa. Cereal Chemistry 70, 303-305.

Repo-Carrasco, R., 2011. Andean Indigenous Food Crops: Nutritional Value and Bioactive

641 Compounds. Doctoral dissertation. University of Turku.

642

643 Repo-Carrasco, R., Esponiza, C., Jacobsen, S.-E., 2003. Nutritional value and use of the 644 Andean crops: quinoa (Chenopodium quinoa) and kañiwa (chenopodium pallidicaule). Food 645 Reviews International 19, 179-189. 
647 Ross, B., Shepherd, J., Schupphaus, M., Sinclair, V., Alfaro, B., Kamal-Eldin, A., Aman, P., 648 2003. Alkylresorcinols in cereal and cereal products. Journal of Agricultural and Food 649 Chemistry 51, 4111-4118.

650

651 Sinopoulos, A.P., 2002. The importance of the ratio of omega-6/omega-3 essential fatty acids.

652 Biomedicine and Pharmacotherapy 56, 365-379.

653

654 
Table 1. Parameters estimates, descriptive and predictive abilities from PLS regression models for response variables as a function of water content of mass (WCM), screw speed (SS) and temperature (TEM). Regression models were calculated using coded values of independent variables

\begin{tabular}{|c|c|c|c|c|c|c|c|c|}
\hline & $\begin{array}{l}\text { Response } \\
\text { variables }\end{array}$ & $\begin{array}{c}\mathbf{x}_{0} \\
\text { Intercept } \\
\end{array}$ & $\begin{array}{c}\mathbf{x}_{1} \\
\text { WCM } \\
\end{array}$ & $\begin{array}{l}\mathbf{x}_{2} \\
\mathrm{SS}\end{array}$ & $\begin{array}{c}\mathbf{x}_{3} \\
\text { TEM } \\
\end{array}$ & $\mathbf{R M S E P}^{\mathrm{f}}$ & $\mathbf{R}^{2}$ & $\mathbf{Q}^{2 g^{657}}$ \\
\hline \multirow[t]{5}{*}{$100 \%$ corn } & $\mathrm{cSEI}^{\mathrm{a}}$ & 11.422 & -0.471 & 0.001 & -0.004 & 0.525 & 0.645 & 0.204 \\
\hline & $\mathrm{cHAR}^{\mathrm{b}}$ & -178.300 & 14.927 & -0.015 & 0.286 & 26.856 & 0.401 & $0.093^{659}$ \\
\hline & $\mathrm{cWCE}^{\mathrm{c}}$ & -16.010 & 1.110 & 0.003 & 0.040 & 2.020 & 0.407 & $0.12 \not 60$ \\
\hline & cTOR $^{\mathrm{d}}$ & 79.765 & -1.356 & -0.016 & -0.110 & 1.334 & 0.810 & 0.59861 \\
\hline & $\mathrm{cPRE}^{\mathrm{e}}$ & 173.630 & -3.526 & -0.057 & -0.363 & 1.617 & 0.965 & 0.859 \\
\hline $20 \%$ amaranth & aSEI & 12.419 & -0.762 & 0.007 & 0.015 & 0.829 & 0.725 & $0.503^{662}$ \\
\hline \multirow[t]{4}{*}{$80 \%$ corn } & aHAR & -156.470 & 16.518 & -0.083 & -0.006 & 15.923 & 0.724 & $0.31 \varsigma^{\oint 63}$ \\
\hline & aWCE & 0.179 & 0.828 & -0.009 & -0.022 & 1.085 & 0.671 & 0.52864 \\
\hline & aTOR & 79.604 & -1.534 & -0.010 & -0.084 & 2.305 & 0.551 & 0.16965 \\
\hline & aPRE & 144.320 & -3.224 & -0.046 & -0.300 & 2.521 & 0.891 & 0.715 \\
\hline $20 \%$ quinoa & qSEI & 8.479 & -0.517 & 0.005 & 0.012 & 0.470 & 0.800 & $0.607^{666}$ \\
\hline \multirow[t]{4}{*}{$80 \%$ corn } & qHAR & -103.430 & 14.357 & -0.081 & -0.048 & 26.364 & 0.427 & $-0.128^{67}$ \\
\hline & qWCE & -7.644 & 0.760 & -0.002 & 0.010 & 0.685 & 0.730 & $0.30 b 68$ \\
\hline & qTOR & 88.091 & -1.095 & -0.024 & -0.142 & 1.353 & 0.851 & $0.70 \frac{3}{669}$ \\
\hline & qPRE & 128.280 & -2.655 & -0.038 & -0.248 & 2.077 & 0.892 & 0.772 \\
\hline $20 \%$ kañiwa & kSEI & 1.805 & -0.332 & 0.007 & 0.026 & 0.361 & 0.869 & $0.818^{670}$ \\
\hline \multirow[t]{4}{*}{$80 \%$ corn } & kHAR & 226.610 & 11.139 & -0.321 & -1.293 & 30.501 & 0.631 & $0.49 \oint 71$ \\
\hline & kWCE & -2.409 & 0.729 & -0.004 & -0.004 & 0.401 & 0.894 & 0.76872 \\
\hline & kTOR & 67.395 & -0.983 & -0.014 & -0.091 & 1.382 & 0.714 & $0.415_{673}$ \\
\hline & $\mathrm{kPRE}$ & 158.210 & -3.631 & -0.041 & -0.286 & 2.460 & 0.896 & 0.700 \\
\hline $\mathrm{VIP}^{\mathrm{h}}$ & & & 1.33 & 1.04 & 0.38 & & & 674 \\
\hline
\end{tabular}

${ }^{\mathrm{a}} \mathrm{SEI}$, sectional expansion index; ${ }^{\mathrm{b}} \mathrm{HAR}$, hardness $\left(\mathrm{N} \mathrm{mm}{ }^{-1}\right) ;{ }^{\mathrm{c}} \mathrm{WCE}$, water content of extrudates $(\%) ;{ }^{\mathrm{d}} \mathrm{TOR}$, torque (Nm); ${ }^{\mathrm{e}} \mathrm{PRE}$, pressure (bar);

\footnotetext{
${ }^{\mathrm{f}} \mathrm{RMSEP}$, root mean square error of prediction; ${ }^{\mathrm{g}} \mathrm{Q}^{2}$, Coefficient of prediction; $\mathrm{VIP}^{\mathrm{h}}$, variable importance on projection.
} 
FIGURE CAPTIONS

678

679

1. PLS weight plot

680

Figure 1. PLS weight plot for independent extrusion parameters ( $\underline{\mathbf{W C M}}$, water

681

682

683

684 content of mass; $\underline{\mathbf{S S}}$, screw speed; $\underline{\mathbf{T E M}}$, temperature) and response variables (SEI, sectional expansion index; HAR, hardness; WCE, water content of extrudate; TOR, torque; PRE, pressure) in which samples codes are $\mathrm{a}=20 \%$ amaranth $/ 80 \%$ corn, $\mathrm{q}=$ $20 \%$ quinoa/ $80 \%$ corn, $\mathrm{k}=20 \%$ kañiwa/ $80 \%$ corn, and $\mathrm{c}=100 \%$ corn.

685

686

2. Contour plots

687

688

689

690

691

Figure 2. Contour plots for sectional expansion index (SEI) and hardness (HAR, N $\mathrm{mm}^{-1}$ ) as a function of screw speed (SS) and water content of mass (WCM) at $160{ }^{\circ} \mathrm{C}$; the effect of temperature of the die on the response variables was not relevant (VIP=0.38). $\quad \mathrm{a}=20 \%$ amaranth $/ 80 \%$ corn; $\mathrm{q}=20 \%$ quinoa/ $80 \%$ corn; $\mathrm{k}=20 \%$ kañiwa/ $80 \%$ corn; and c= $100 \%$ corn.

692

693

3. Cross-sectional area of extrudates

694

695

696

697

Figure 3. Cross-sectional area of corn-based extrudates containing $20 \%$ amaranth (A), 20\% quinoa (B), $20 \%$ kañiwa (C) and 100\% corn (D); comparison of crosssectional areas (E). Samples were obtained from the experiment 2 (WCM 15\%, SS $550 \mathrm{rpm}$, TEM $\left.160^{\circ} \mathrm{C}\right)$.

698

699

700

701 
702

703

704

705

706

707

708

709

710

711

712

713

714

715

716

717

718

719

720

721

722

723

724

725

726

4. X-ray scattering plot

Figure 4. X-ray scattering intensities of milled extrudates (experiment 2) containing $20 \%$ amaranth (a), 20\% quinoa (b), 20\% kañiwa (c) and 100\% corn (d), shifted vertically for clarity.

5. Curves of hexanal production

Figure 5. Production of hexanal in ground and whole extrudates containing $20 \%$ amaranth $(\diamond), 20 \%$ quinoa $(\square), 20 \%$ kañiwa $(\triangle)$ and $100 \%$ corn $(\bigcirc)$. Error bar shows \pm standard deviation.

(1)

2

(1)

(1)


727

728

729

730

731

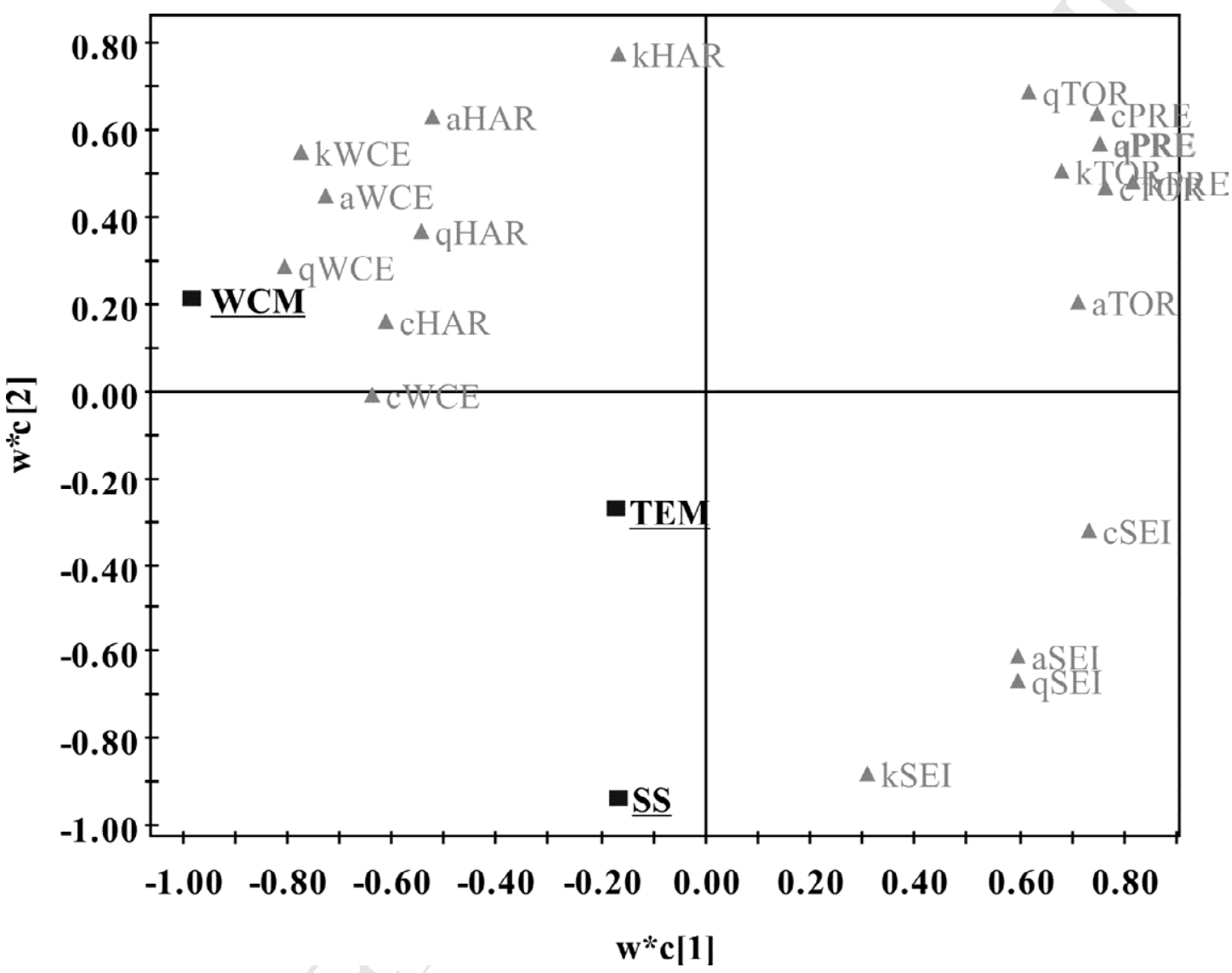

\section{FIGURES}

1. PLS weight plot

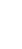

732

733

734

735

736

737

738

739 
741
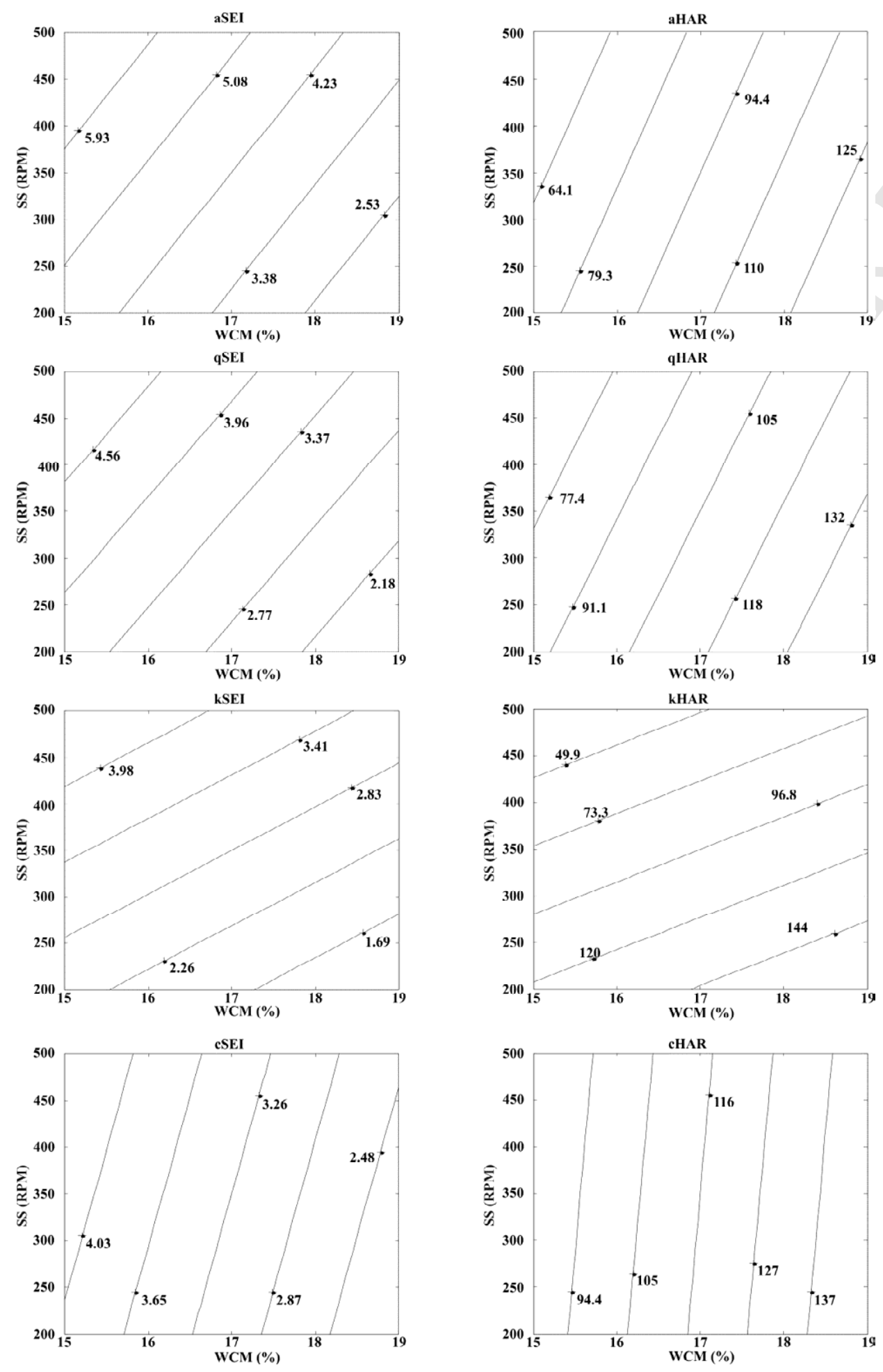


\section{Cross-sectional area of extrudates}
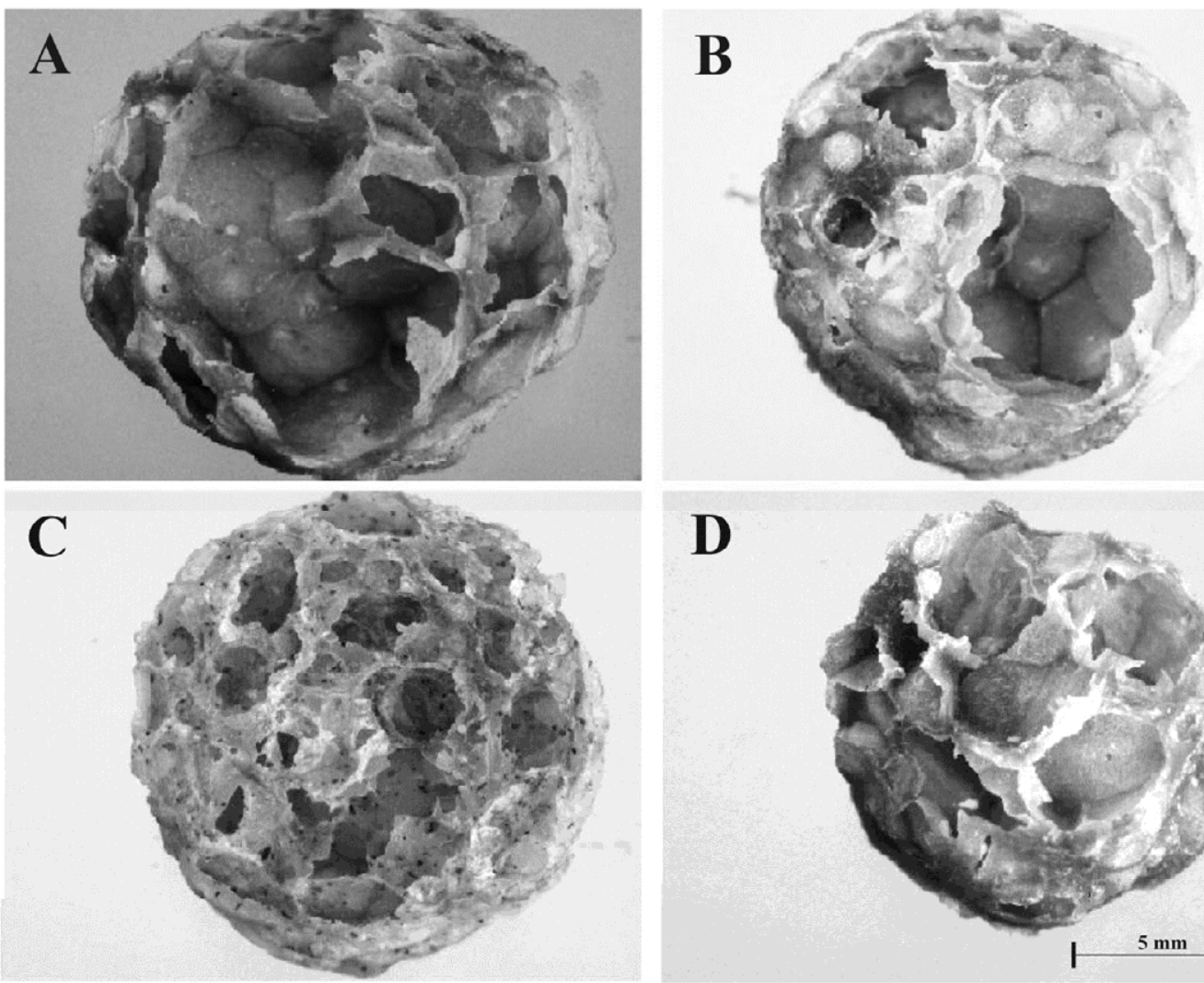

D
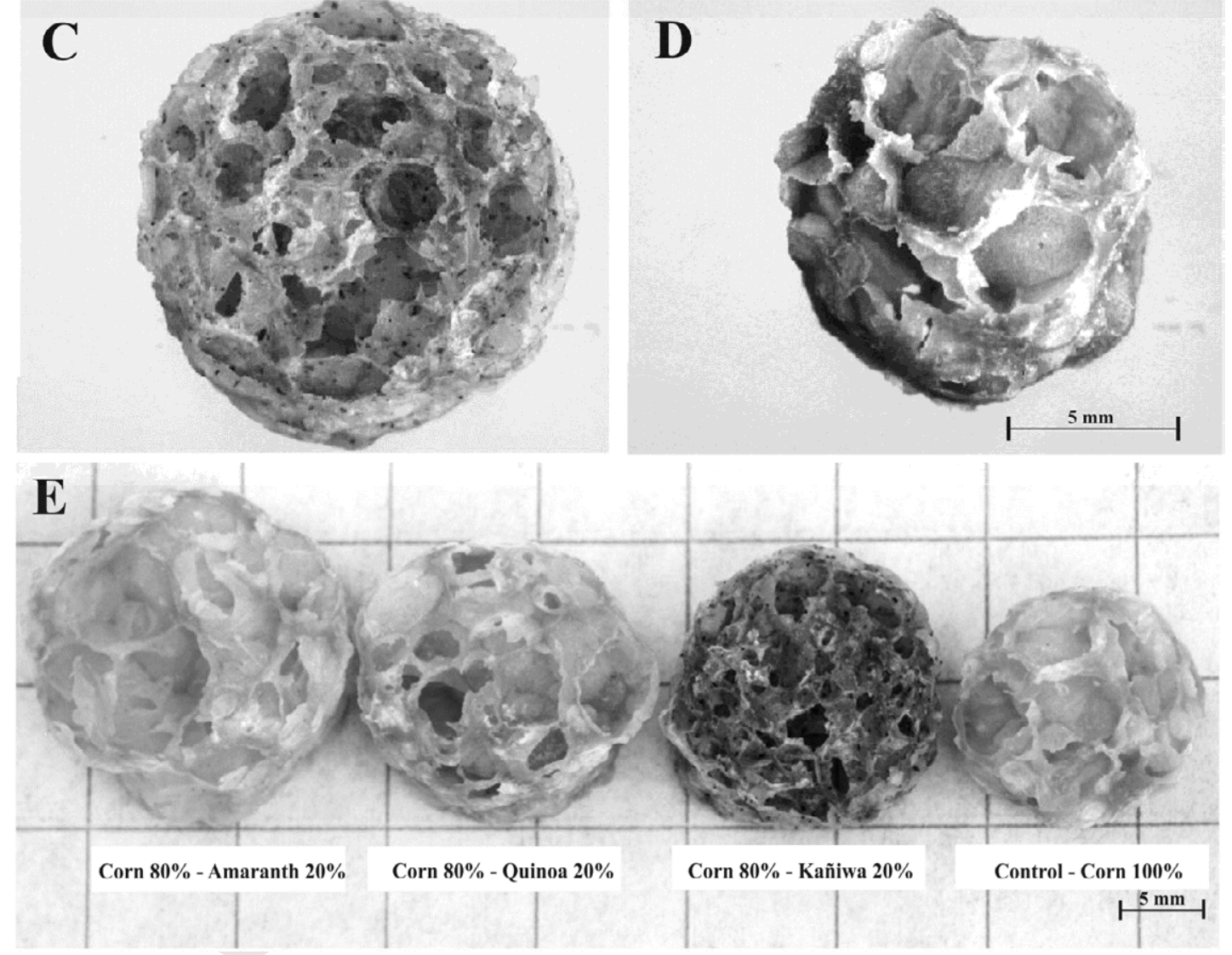

746

747

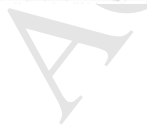

748 
4. X-ray scattering plot

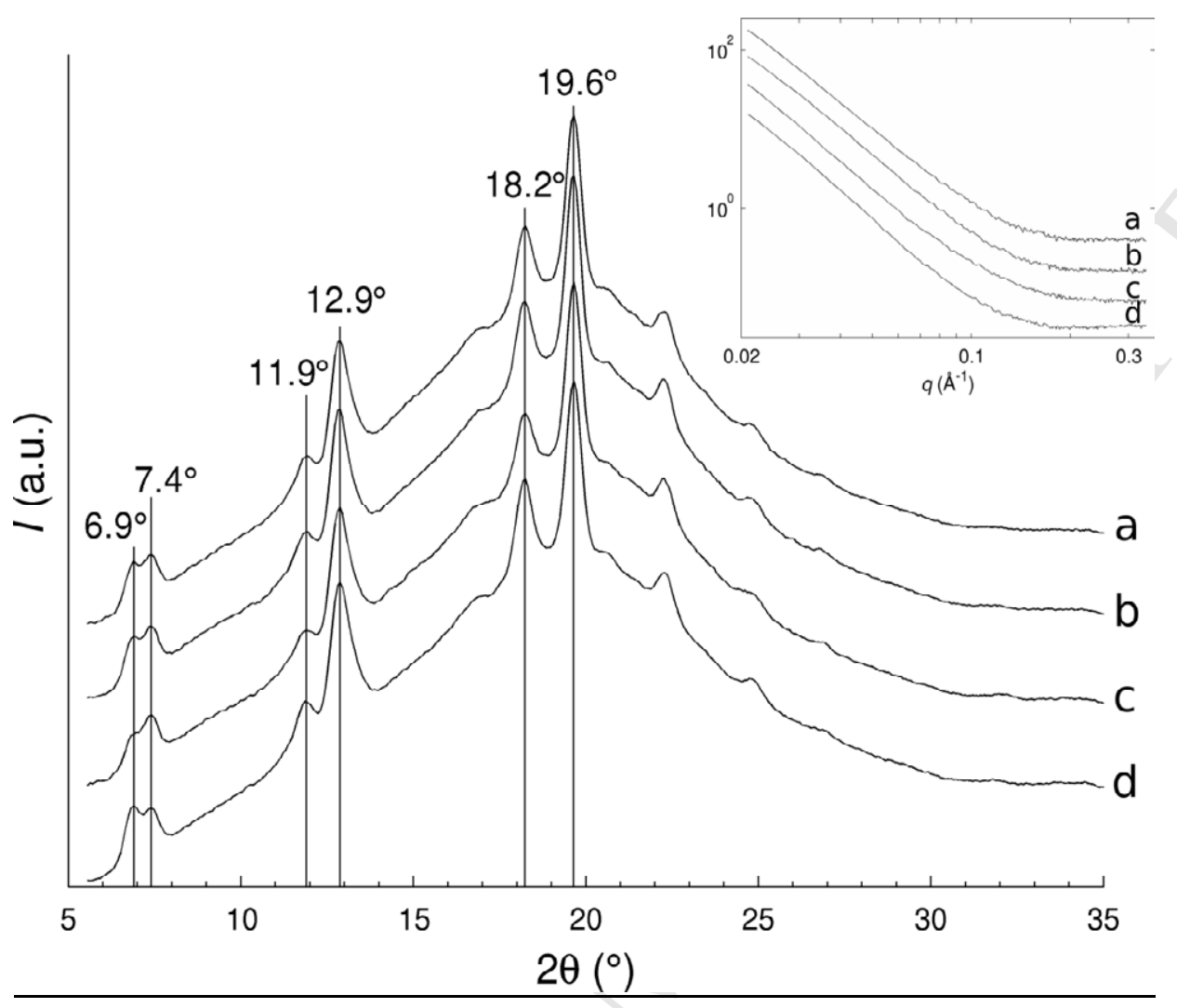

753

754

755

756

757

758

759

760

761

762

763

764 
A

Humidity exposure: $11 \%$ ERH

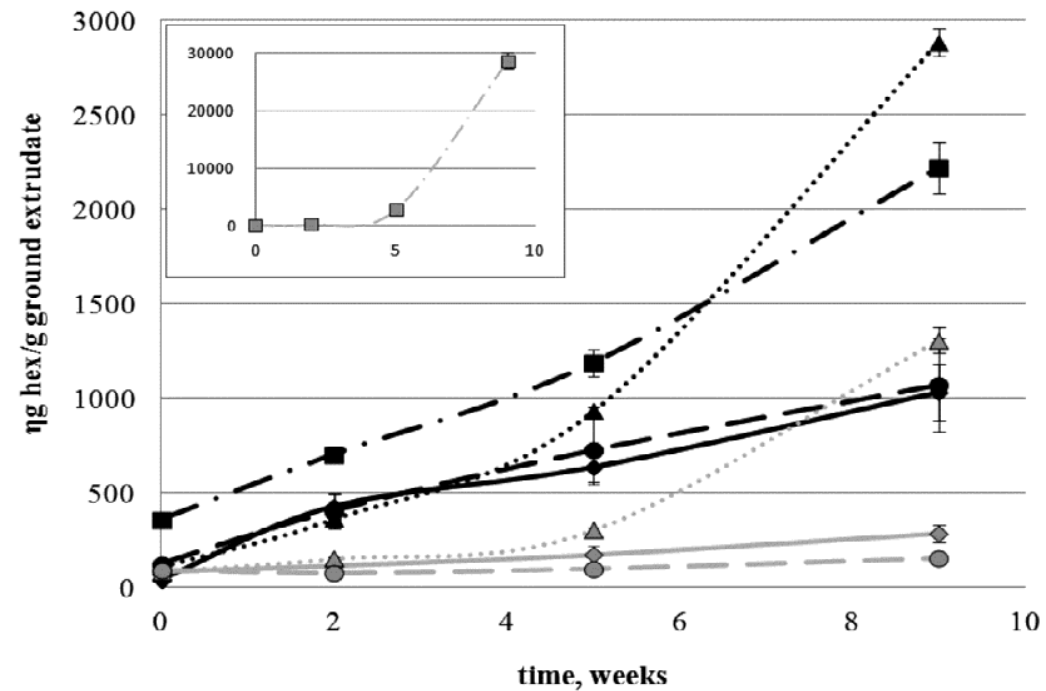

B

Humidity exposure: $76 \%$ ERH

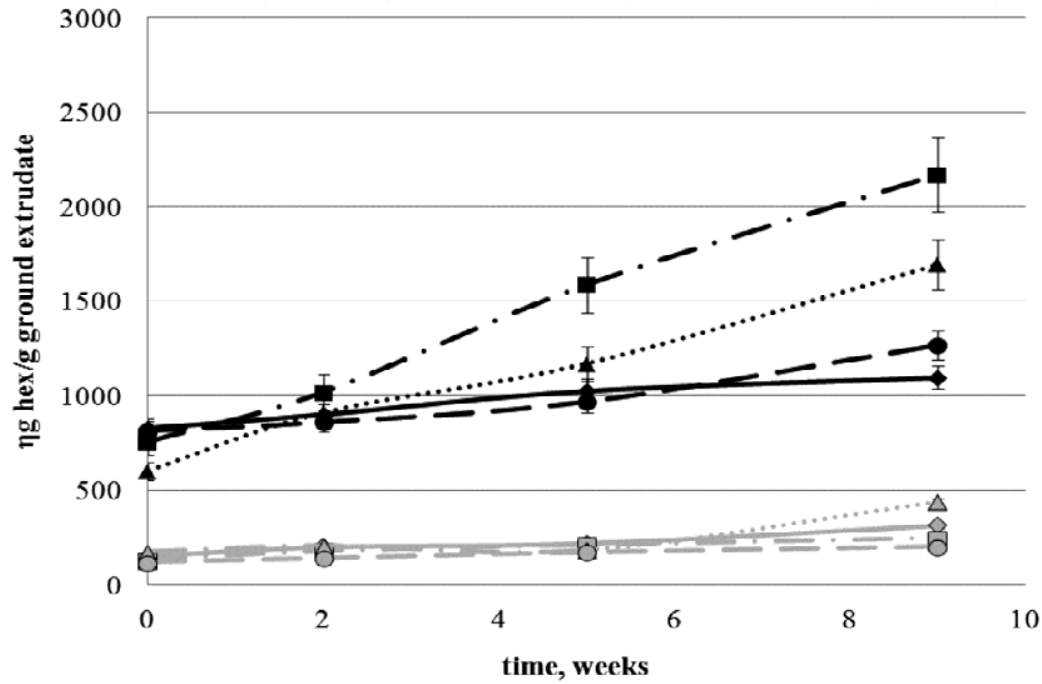




\section{APPENDICES}

Appendix A. Chemical composition of amaranth var. Centenario, quinoa var. Rosada de Huancayo, kañiwa var. Cupi and corn. Results on dry basis except for moisture content.

\begin{tabular}{|c|c|c|c|c|c|c|c|c|c|c|c|}
\hline & \multirow{2}{*}{$\begin{array}{c}\text { Moisture content, } \\
\text { g/100 g original } \\
\text { sample }\end{array}$} & \multicolumn{6}{|c|}{$\begin{array}{c}\text { Content of solids, } \\
\text { \% of solids }\end{array}$} & \multicolumn{2}{|c|}{$\begin{array}{c}\text { Tocopherol content, } \\
\mu \mathrm{g} / \mathrm{g} \text { of solid }\end{array}$} & \multicolumn{2}{|c|}{$\begin{array}{c}\text { Fatty acid content, } \\
\% \text { total fatty acid }\end{array}$} \\
\hline & & Protein & Fat & $\begin{array}{l}\text { Dietary } \\
\text { fiber }\end{array}$ & Ash & $\begin{array}{l}\text { Digestible } \\
\text { CHO* }\end{array}$ & Sugar** & $\begin{array}{c}\alpha- \\
\text { Tocopherol }\end{array}$ & $\begin{array}{c}\beta \text { - } \\
\text { Tocopherol }\end{array}$ & C18:1 n-9 & C18:2 n-6 \\
\hline Amaranth & $10.6 \pm 0.13$ & $12.2 \pm 0.20$ & $6.6 \pm 0.19$ & $8.6 \pm 0.12$ & $2.1 \pm 0.002$ & 71 & $2.5-3.8^{\mathrm{e}}$ & $7.84 \pm 0.10$ & $19.02 \pm 0.26$ & $26.95 \pm 1.44$ & $42.99 \pm 1.47$ \\
\hline Quinoa & $11.6 \pm 0.14$ & $16.4 \pm 0.55$ & $6.3 \pm 0.29$ & $11.5 \pm 0.19$ & $3.2 \pm 0.06$ & 63 & $2.7^{\mathrm{f}}$ & $23.69 \pm 0.09$ & $0.76 \pm 0.01$ & $24.78 \pm 1.10$ & $50.40 \pm 1.30$ \\
\hline Kañiwa & $9.1 \pm 0.15$ & $15.6 \pm 0.004$ & $8.7 \pm 0.39$ & $20.5 \pm 0.91$ & $4.0 \pm 0.03$ & 51 & $\mathrm{NF}$ & $17.90 \pm 0.29$ & $0.95 \pm 0.03$ & $25.49 \pm 0.35$ & $47.89 \pm 0.72$ \\
\hline Corn & $9.4 \pm 0.026$ & $6-9^{a}$ & $2.05 \pm 0.06$ & $<1^{\mathrm{a}, \mathrm{b}}$ & $<1^{\mathrm{a}}$ & $>75^{\mathrm{a}, \mathrm{c}}$ & $1.4-2^{\mathrm{g}}$ & $5.84^{\mathrm{d}}$ & $0.56^{\mathrm{d}}$ & $26.98 \pm 0.003$ & $54.66 \pm 0.02$ \\
\hline
\end{tabular}

${ }^{\mathrm{a}}$ Values provided by Limagrain ${ }^{\circledR}$ on dry basis $/{ }^{\mathrm{b}}$ Cellulose content $/{ }^{\mathrm{c}}$ Starch content $/{ }^{\mathrm{d}}$ Analysis in duplicate/ NF=not found

${ }^{\mathrm{e}}$ Pedersen, B., Kalinowski, L.S., Eggum, B.O.,1987. The nutritive value of amaranth grain (Amaranthus caudatus). 1. Protein and minerals of raw and processed grain. Plant Foods for Human Nutrition 36, 309-234.

${ }^{\mathrm{f}}$ Ranhotra, G.S., Gelroth, J.A., Glaser, B.K., Lorenz, K.J., Johnson, D.L., 1993. Composition and protein nutritional quality of quinoa. Cereal Chemistry 70, 303305.

${ }^{\mathrm{g}}$ Rooney, L.W., McDonough, C.M., Waniska, R.D. The corn kernel. In: Smith, C.W., Bentran, J., Runge, E.C.A. (Eds.), Corn origin, history, technology, and production. John Wiley \& Sons Inc., New Jersey, pp. 288-289.

*Digestible carbohydrates $(\mathrm{CHO})=100-($ protein + fat + dietary fiber + ash $)$

**Monosaccharides, disaccharides or oligosaccharides that might act as plasticizers in the mass. 
Appendix B. Coded and actual values for 3 independent variables.

\section{Coded values}

\begin{tabular}{cccc}
\cline { 2 - 2 } Experiments* $^{*}$ & $X_{1}{ }^{a}$ & $X_{2}{ }^{b}$ & $X_{3}{ }^{c}$
\end{tabular}

\begin{tabular}{|c|c|c|c|c|c|c|}
\hline Experiments* & $X_{I}^{a}$ & $X_{2}^{b}$ & $X_{3}^{c}$ & $A^{a}$ & $\boldsymbol{B}^{b}$ & $C^{c}$ \\
\hline 11 & 1 & 0 & -1 & 19 & 350 & 150 \\
\hline 3 & -1 & 0 & -1 & 15 & 350 & 150 \\
\hline 5 & 0 & -1 & -1 & 17 & 200 & 150 \\
\hline 7 & 0 & 1 & -1 & 17 & 500 & 150 \\
\hline 15 & 0 & 0 & 0 & 17 & 350 & 160 \\
\hline 1 & -1 & -1 & 0 & 15 & 200 & 160 \\
\hline 2 & -1 & 1 & 0 & 15 & 500 & 160 \\
\hline 13 & 0 & 0 & 0 & 17 & 350 & 160 \\
\hline 9 & 1 & -1 & 0 & 19 & 200 & 160 \\
\hline 10 & 1 & 1 & 0 & 19 & 500 & 160 \\
\hline 14 & 0 & 0 & 0 & 17 & 350 & 160 \\
\hline 6 & 0 & -1 & 1 & 17 & 200 & 170 \\
\hline 8 & 0 & 1 & 1 & 17 & 500 & 170 \\
\hline 12 & 1 & 0 & 1 & 19 & 350 & 170 \\
\hline 4 & -1 & 0 & 1 & 15 & 350 & 170 \\
\hline
\end{tabular}

782

783

784

785

786

787

788

789

790

791

792

\section{Actual values}

${ }^{\mathrm{a}} X_{l}$ and $A$, water content of mass (\%)

${ }^{\mathrm{b}} X_{2}$ and $B$, screw speed (rpm)

${ }^{\mathrm{c}} \mathrm{X}_{3}$ and $C$, temperature of the die $\left({ }^{\circ} \mathrm{C}\right)$

*The order of the experiments is following the increasing temperature of the die 
793

794

795

796

797

798

799

800

801

Appendix C1. External standard curves for ground extrudate. Sample mass: $2 \mathrm{~g}$.

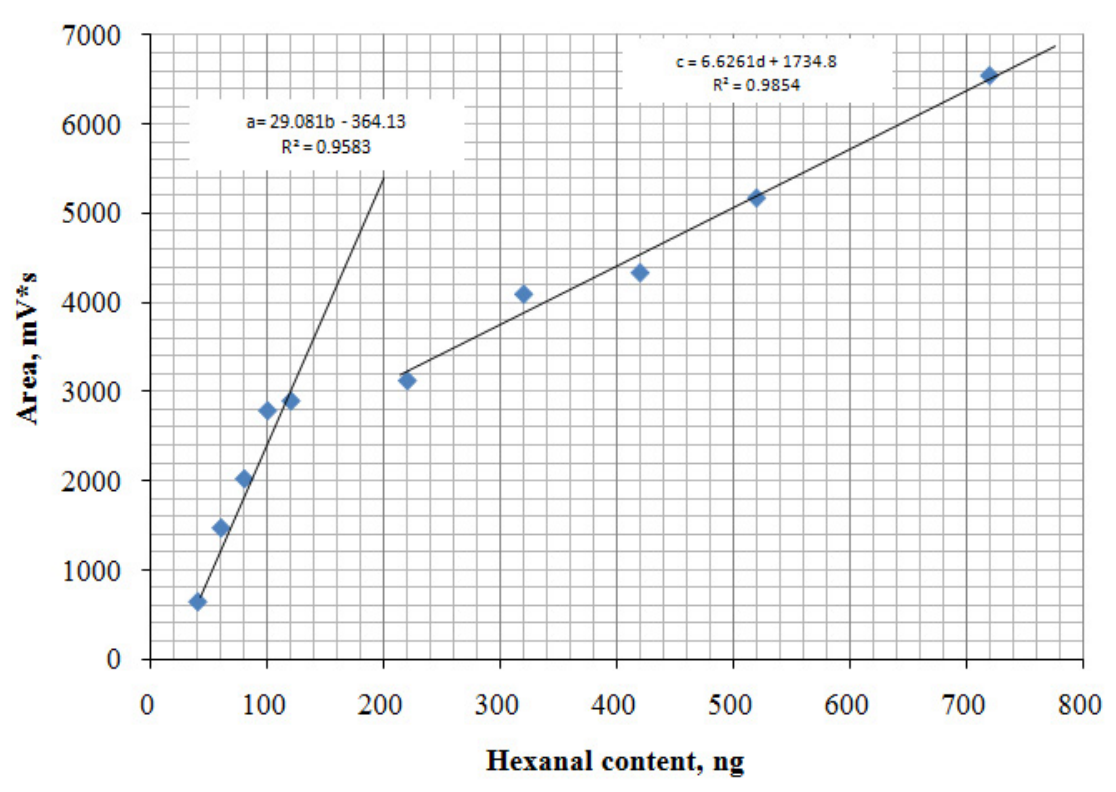

Appendix C2. External standard curves for whole extrudate. Sample mass: $0.5 \mathrm{~g}$.

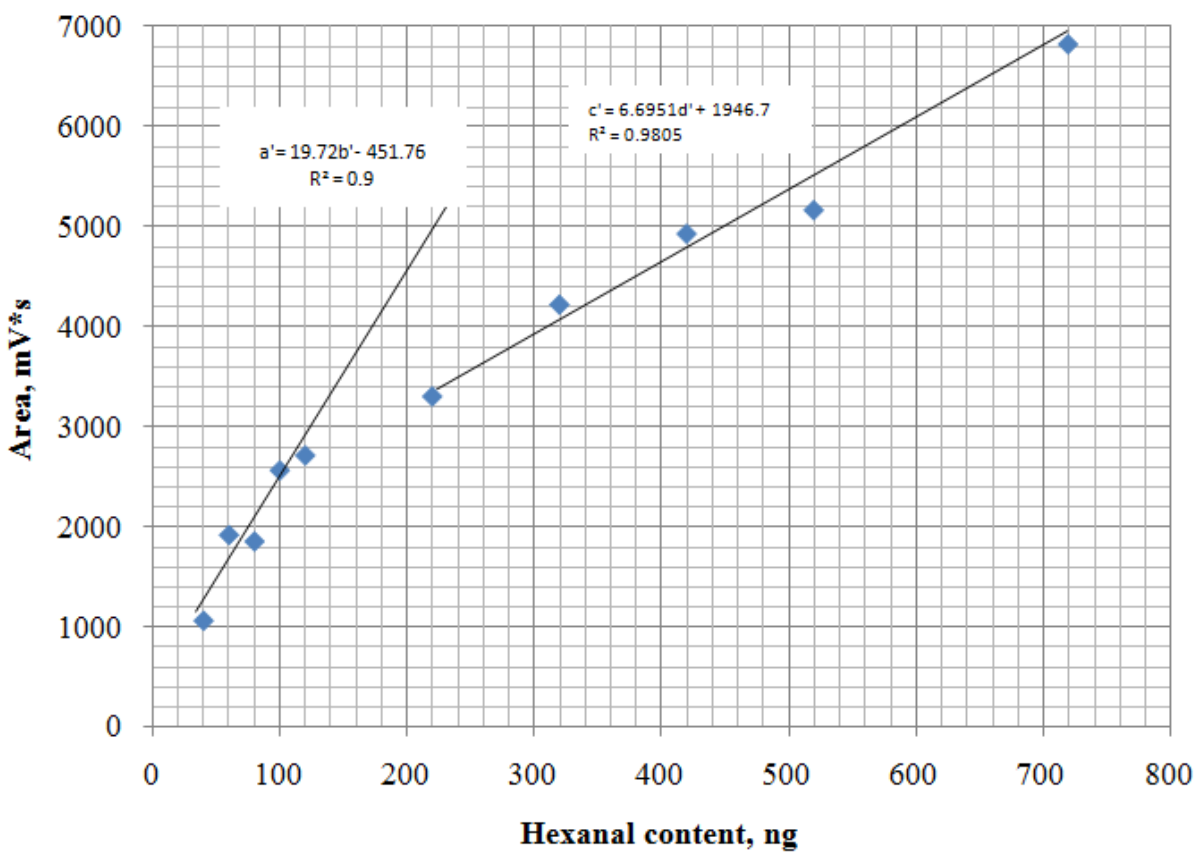


802

803

804

805

806

807

808

809

810

811

812

813

814

815

816

\section{9}

Appendix D. Longitudinal section of corn-based extrudates containing $20 \%$ amaranth (A), $20 \%$

quinoa (B), 20\% kañiwa (C) and 100\% corn (D). Samples from experiment 2 (WCM 15\%, SS 500 rpm, TEM $160{ }^{\circ} \mathrm{C}$ )
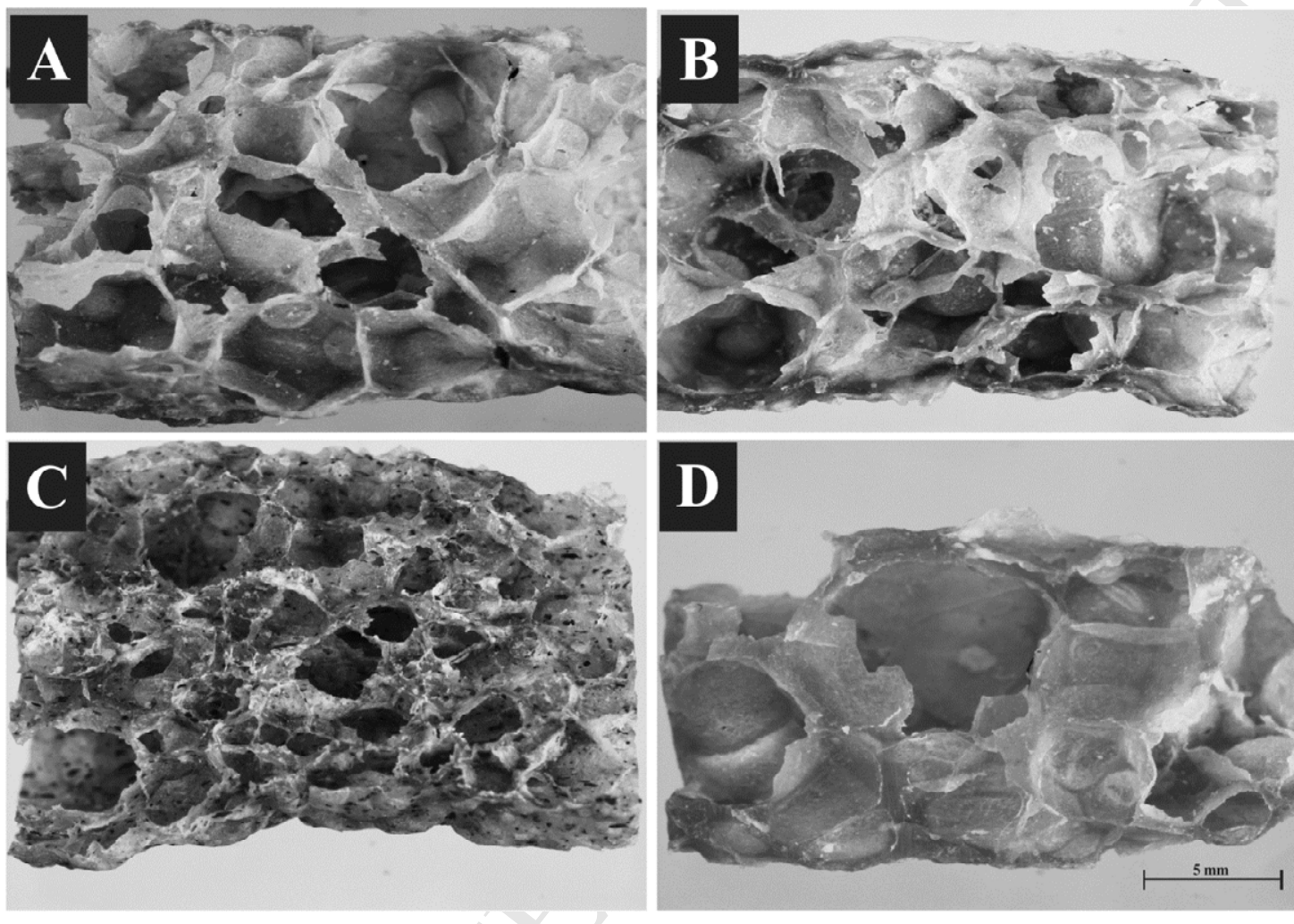

\section{D}

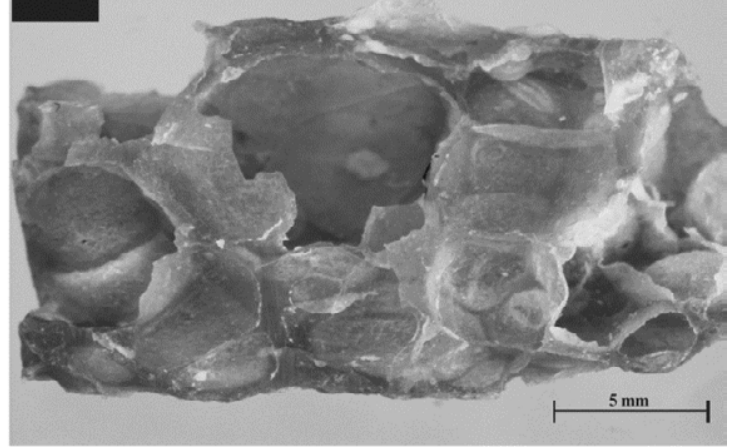

10

.

2


$819{ }^{1}$ Water present in the material fed to the extruder. 


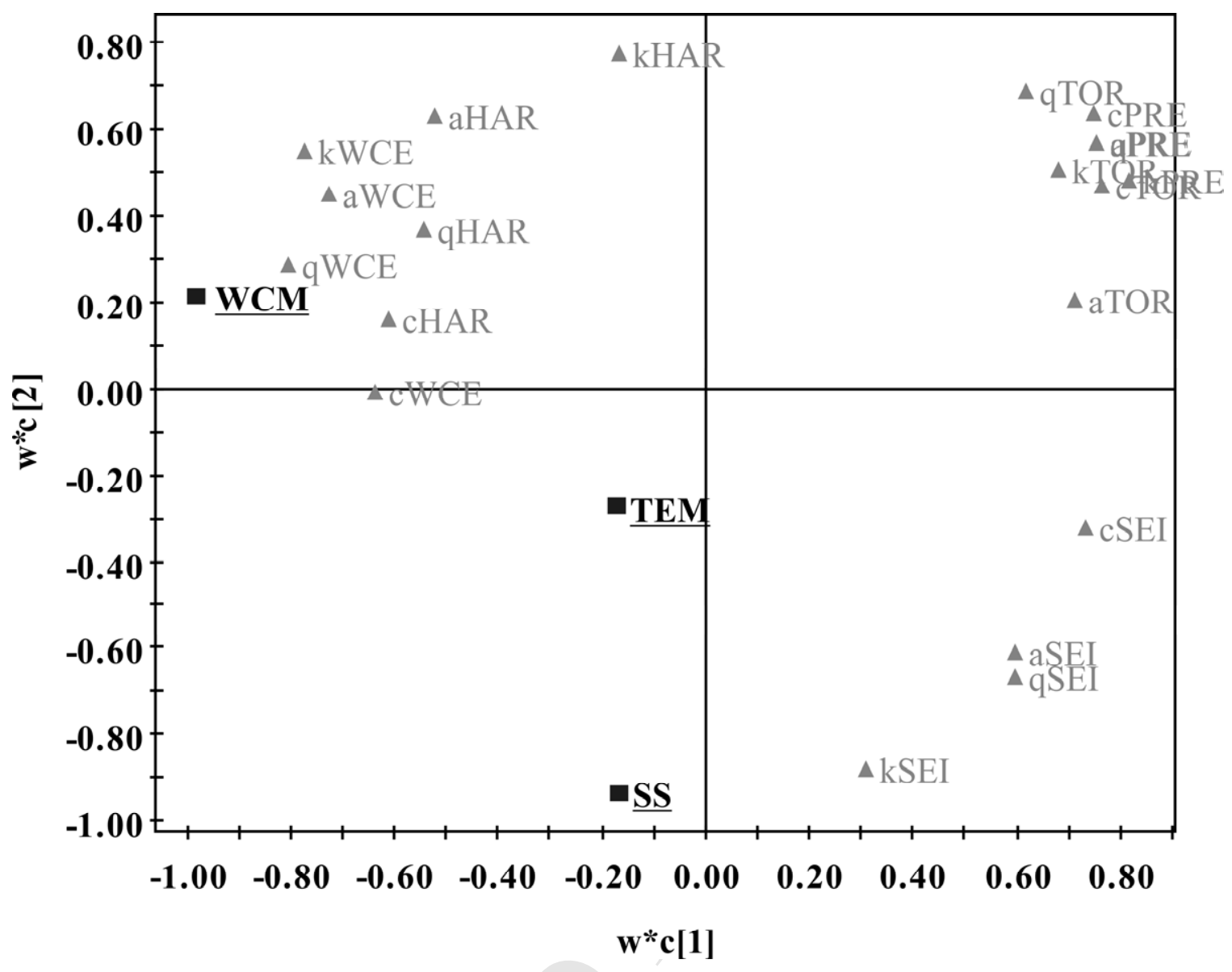



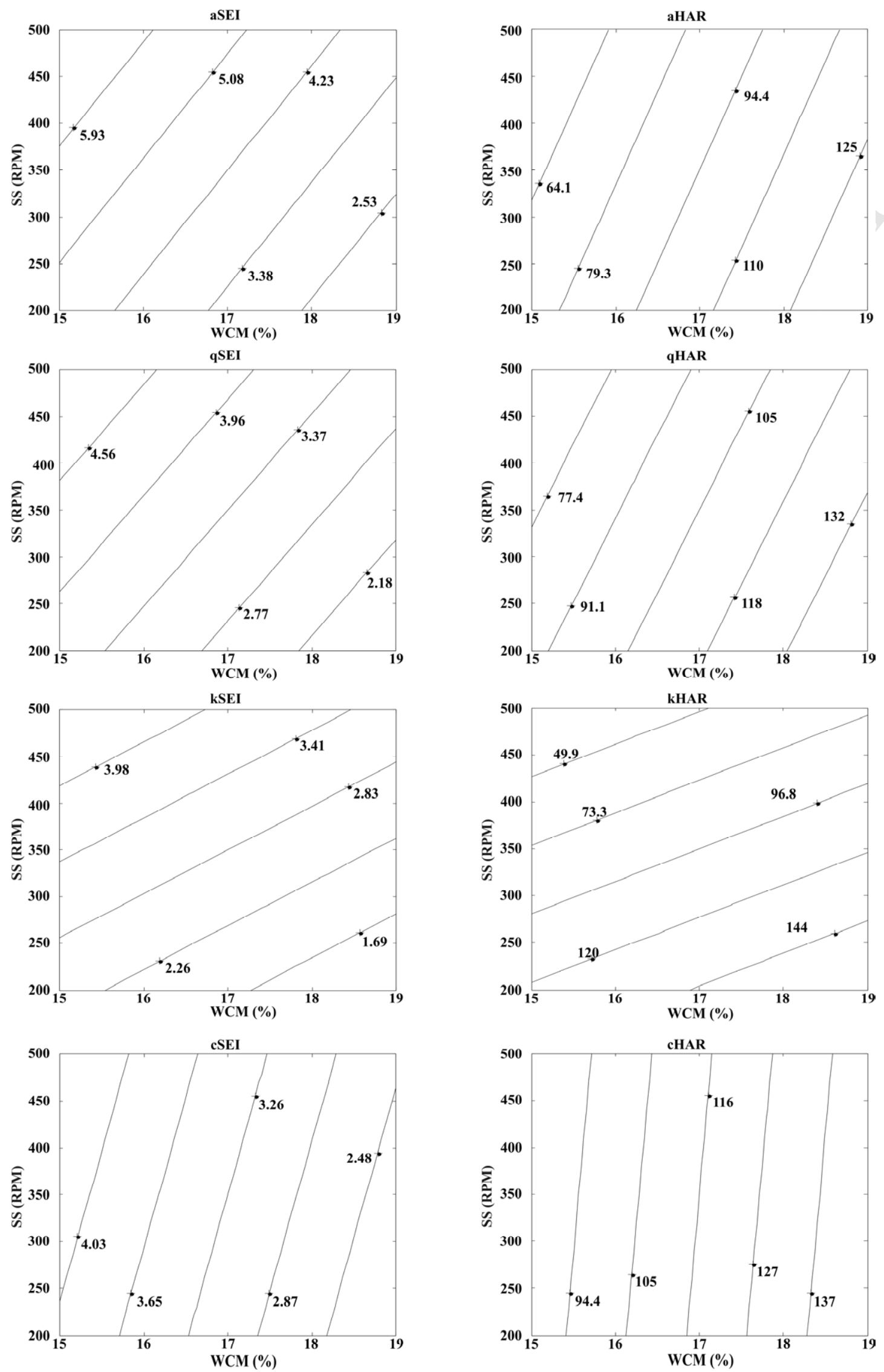

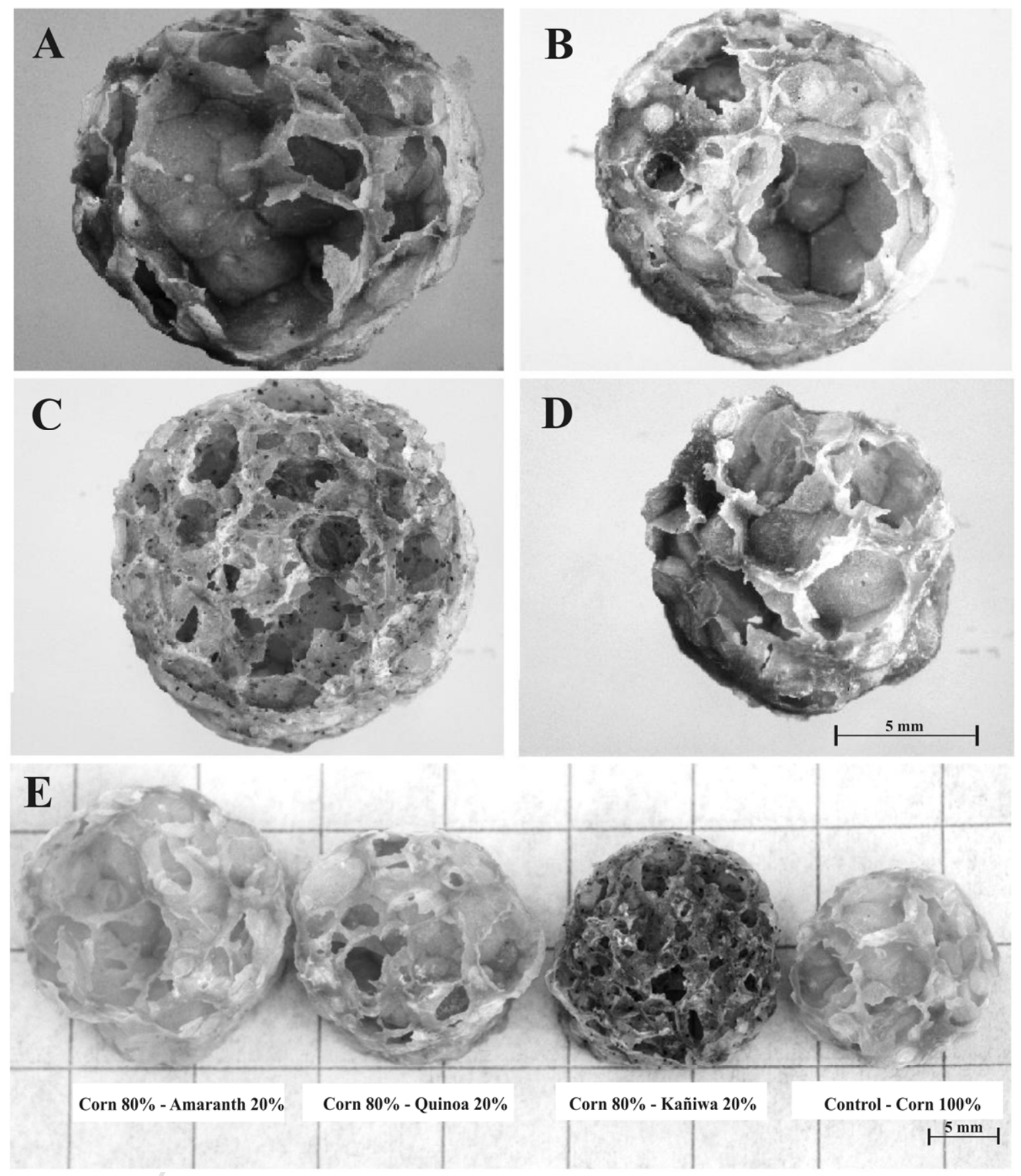


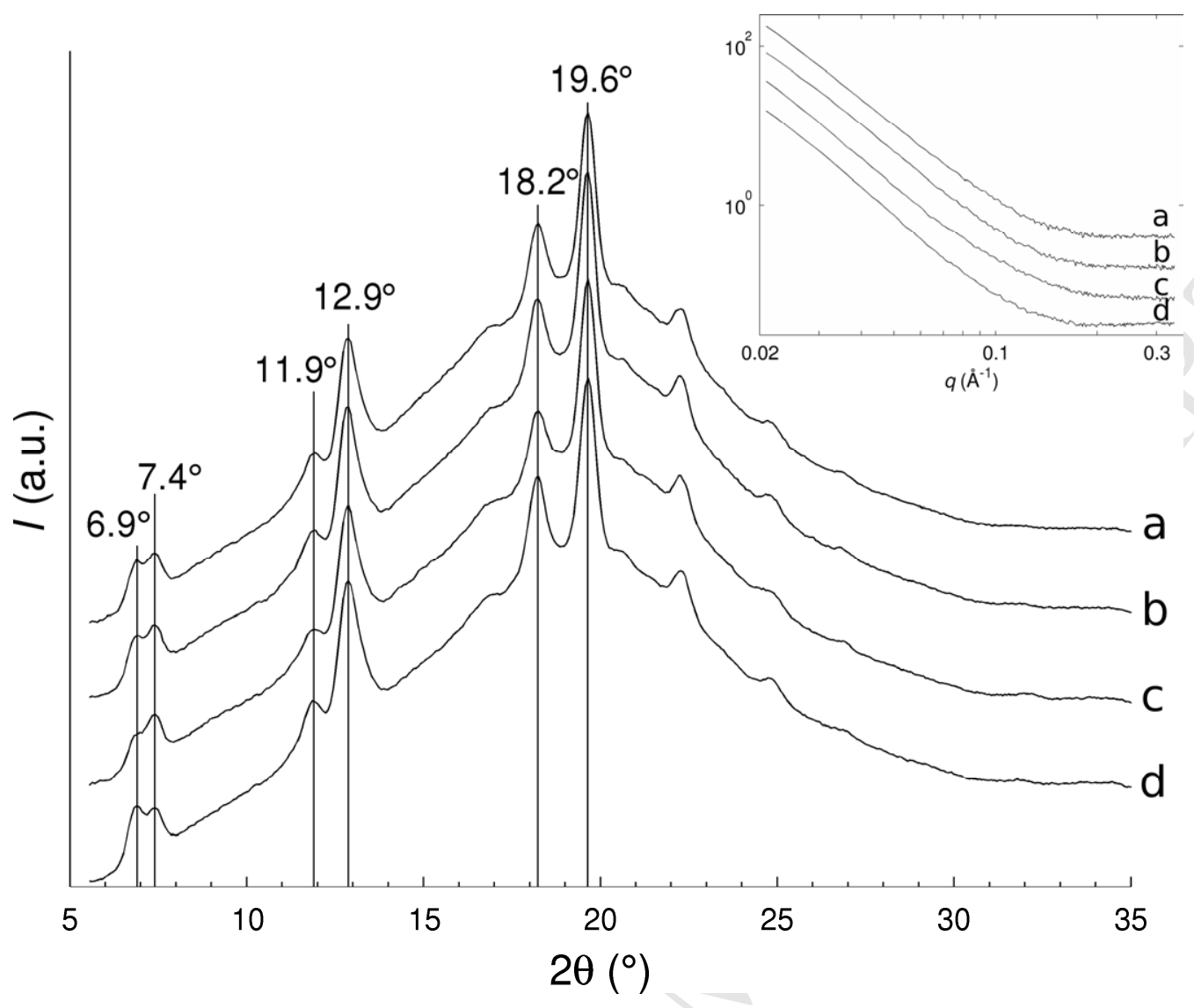


A

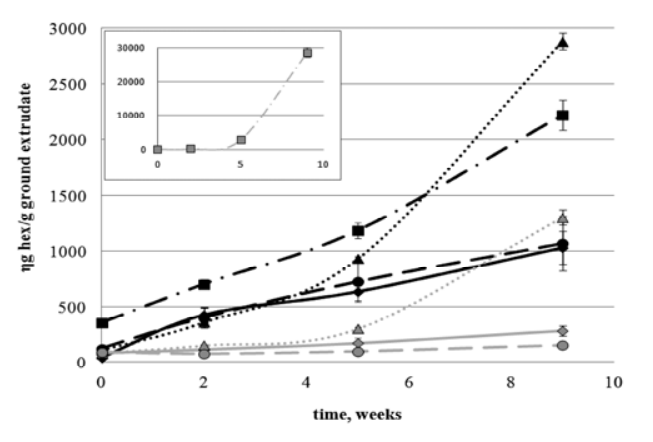

B

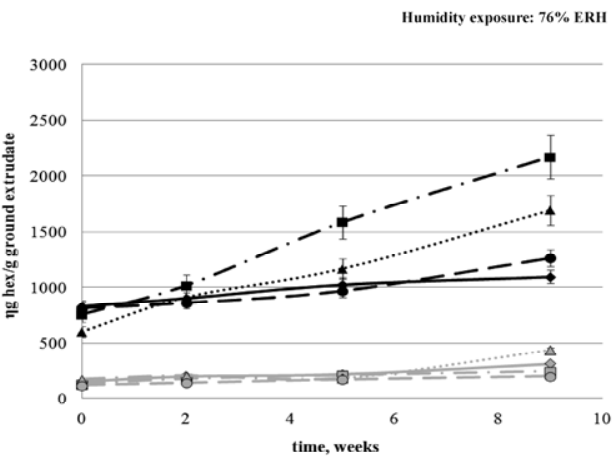




\section{APPENDICES}

2 Appendix A. Chemical composition of amaranth var. Centenario, quinoa var. Rosada de Huancayo, kañiwa var. Cupi and corn. Results on dry basis except for 3 moisture content.

\begin{tabular}{|c|c|c|c|c|c|c|c|c|c|c|c|}
\hline & \multirow{2}{*}{$\begin{array}{c}\text { Moisture content, } \\
\text { g/100 g original } \\
\text { sample }\end{array}$} & \multicolumn{6}{|c|}{$\begin{array}{c}\text { Content of solids, } \\
\text { \% of solids }\end{array}$} & \multicolumn{2}{|c|}{$\begin{array}{c}\text { Tocopherol content, } \\
\mu \mathrm{g} / \mathrm{g} \text { of solid }\end{array}$} & \multicolumn{2}{|c|}{$\begin{array}{l}\text { Fatty acid content, } \\
\% \text { total fatty acid }\end{array}$} \\
\hline & & Protein & Fat & $\begin{array}{l}\text { Dietary } \\
\text { fiber }\end{array}$ & Ash & $\begin{array}{c}\text { Digestible } \\
\text { CHO* }\end{array}$ & Sugar** & $\begin{array}{c}\alpha- \\
\text { Tocopherol }\end{array}$ & $\begin{array}{c}\beta- \\
\text { Tocopherol }\end{array}$ & C18:1 n-9 & C18:2 n-6 \\
\hline Amaranth & $10.6 \pm 0.13$ & $12.2 \pm 0.20$ & $6.6 \pm 0.19$ & $8.6 \pm 0.12$ & $2.1 \pm 0.002$ & 71 & $2.5-3.8^{\mathrm{e}}$ & $7.84 \pm 0.10$ & $19.02 \pm 0.26$ & $26.95 \pm 1.44$ & $42.99 \pm 1.47$ \\
\hline Quinoa & $11.6 \pm 0.14$ & $16.4 \pm 0.55$ & $6.3 \pm 0.29$ & $11.5 \pm 0.19$ & $3.2 \pm 0.06$ & 63 & $2.7^{\mathrm{f}}$ & $23.69 \pm 0.09$ & $0.76 \pm 0.01$ & $24.78 \pm 1.10$ & $50.40 \pm 1.30$ \\
\hline Kañiwa & $9.1 \pm 0.15$ & $15.6 \pm 0.004$ & $8.7 \pm 0.39$ & $20.5 \pm 0.91$ & $4.0 \pm 0.03$ & 51 & $\mathrm{NF}$ & $17.90 \pm 0.29$ & $0.95 \pm 0.03$ & $25.49 \pm 0.35$ & $47.89 \pm 0.72$ \\
\hline Corn & $9.4 \pm 0.026$ & $6-9^{a}$ & $2.05 \pm 0.06$ & $<1^{\mathrm{a}, \mathrm{b}}$ & $<1^{\mathrm{a}}$ & $>75^{a, c}$ & $1.4-2^{\mathrm{g}}$ & $5.84^{\mathrm{d}}$ & $0.56^{\mathrm{d}}$ & $26.98 \pm 0.003$ & $54.66 \pm 0.02$ \\
\hline
\end{tabular}

$4 \quad{ }^{\mathrm{a}}$ Values provided by Limagrain ${ }^{\circledR}$ on dry basis $/{ }^{\mathrm{b}}$ Cellulose content $/{ }^{\mathrm{c}}$ Starch content $/{ }^{\mathrm{d}}$ Analysis in duplicate/ NF=not found

$5 \quad{ }^{\mathrm{e}}$ Pedersen, B., Kalinowski, L.S., Eggum, B.O.,1987. The nutritive value of amaranth grain (Amaranthus caudatus). 1. Protein and minerals of raw and processed 6 grain. Plant Foods for Human Nutrition 36, 309-234.

$7 \quad{ }^{\mathrm{f}}$ Ranhotra, G.S., Gelroth, J.A., Glaser, B.K., Lorenz, K.J., Johnson, D.L., 1993. Composition and protein nutritional quality of quinoa. Cereal Chemistry 70, 3038305.

$9 \quad$ g Rooney, L.W., McDonough, C.M., Waniska, R.D. The corn kernel. In: Smith, C.W., Bentran, J., Runge, E.C.A. (Eds.), Corn origin, history, technology, and 10 production. John Wiley \& Sons Inc., New Jersey, pp. 288-289.

11 *Digestible carbohydrates $(\mathrm{CHO})=100-($ protein + fat + dietary fiber + ash $)$

$12 * *$ Monosaccharides, disaccharides or oligosaccharides that might act as plasticizers in the mass. 
14 Appendix B. Coded and actual values for 3 independent variables.

\begin{tabular}{|c|c|c|c|c|c|c|}
\hline \multirow[b]{2}{*}{ Experiments* } & \multicolumn{3}{|c|}{ Coded values } & \multicolumn{3}{|c|}{ Actual values } \\
\hline & $X_{1}^{a}$ & $X_{2}^{b}$ & $X_{3}^{c}$ & $A^{a}$ & $B^{b}$ & $C^{c}$ \\
\hline 11 & 1 & 0 & -1 & 19 & 350 & 150 \\
\hline 3 & -1 & 0 & -1 & 15 & 350 & 150 \\
\hline 5 & 0 & -1 & -1 & 17 & 200 & 150 \\
\hline 7 & 0 & 1 & -1 & 17 & 500 & 150 \\
\hline 15 & 0 & 0 & 0 & 17 & 350 & 160 \\
\hline 1 & -1 & -1 & 0 & 15 & 200 & 160 \\
\hline 2 & -1 & 1 & 0 & 15 & 500 & 160 \\
\hline 13 & 0 & 0 & 0 & 17 & 350 & 160 \\
\hline 9 & 1 & -1 & 0 & 19 & 200 & 160 \\
\hline 10 & 1 & 1 & 0 & 19 & 500 & 160 \\
\hline 14 & 0 & 0 & 0 & 17 & 350 & 160 \\
\hline 6 & 0 & -1 & 1 & 17 & 200 & 170 \\
\hline 8 & 0 & 1 & 1 & 17 & 500 & 170 \\
\hline 12 & 1 & 0 & 1 & 19 & 350 & 170 \\
\hline 4 & -1 & 0 & 1 & 15 & 350 & 170 \\
\hline \multicolumn{7}{|c|}{15} \\
\hline \multicolumn{7}{|c|}{${ }^{\mathrm{a}} X_{l}$ and $A$, water content of mass (\%) } \\
\hline \multirow{2}{*}{\multicolumn{7}{|c|}{$\begin{array}{l}{ }^{\mathrm{b}} X_{2} \text { and } B \text {, screw speed (rpm) } \\
{ }^{\mathrm{c}} X_{3} \text { and } C \text {, temperature of the die }\left({ }^{\circ} \mathrm{C}\right)\end{array}$}} \\
\hline & & & & & & \\
\hline \multicolumn{7}{|c|}{ *The order of the experiments is following the increasing temperature of the die } \\
\hline & & & & & & \\
\hline & & & & & & \\
\hline & & & & & & \\
\hline & & & & & & \\
\hline & & & & & & \\
\hline & & & & & & \\
\hline & & & & & & \\
\hline
\end{tabular}


27 Appendix C1. External standard curves for ground extrudate. Sample mass: $2 \mathrm{~g}$.

28

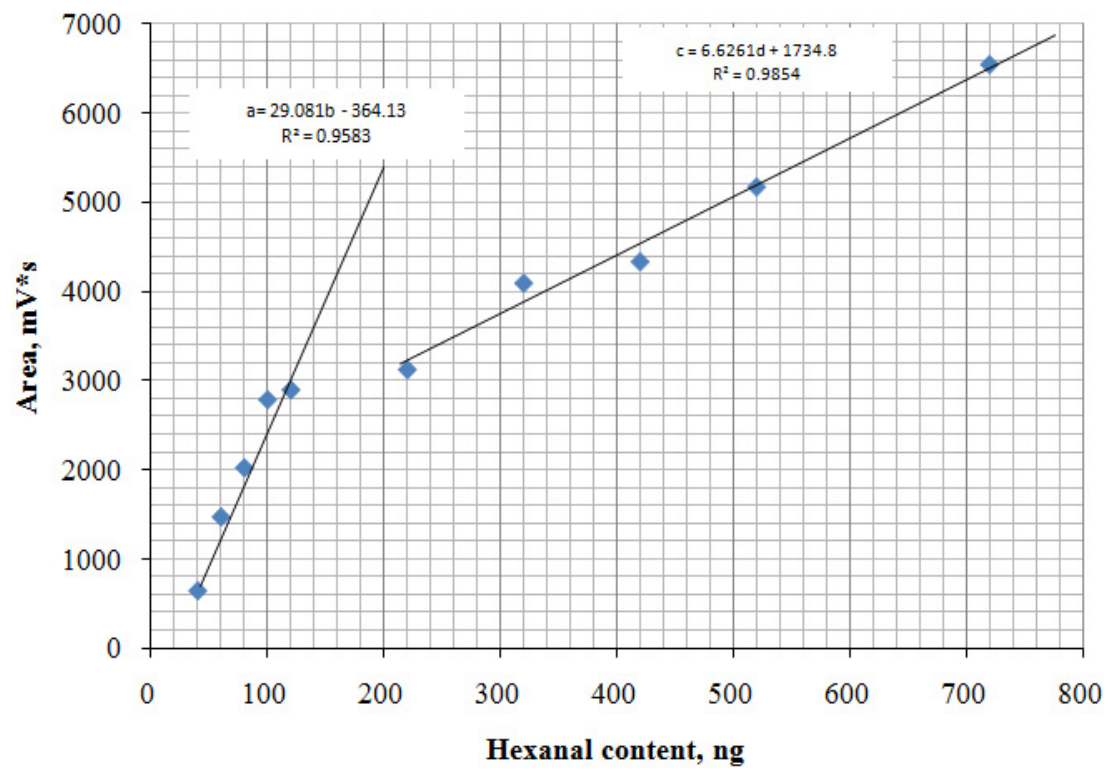

29

Appendix C2. External standard curves for whole extrudate. Sample mass: $0.5 \mathrm{~g}$.

31

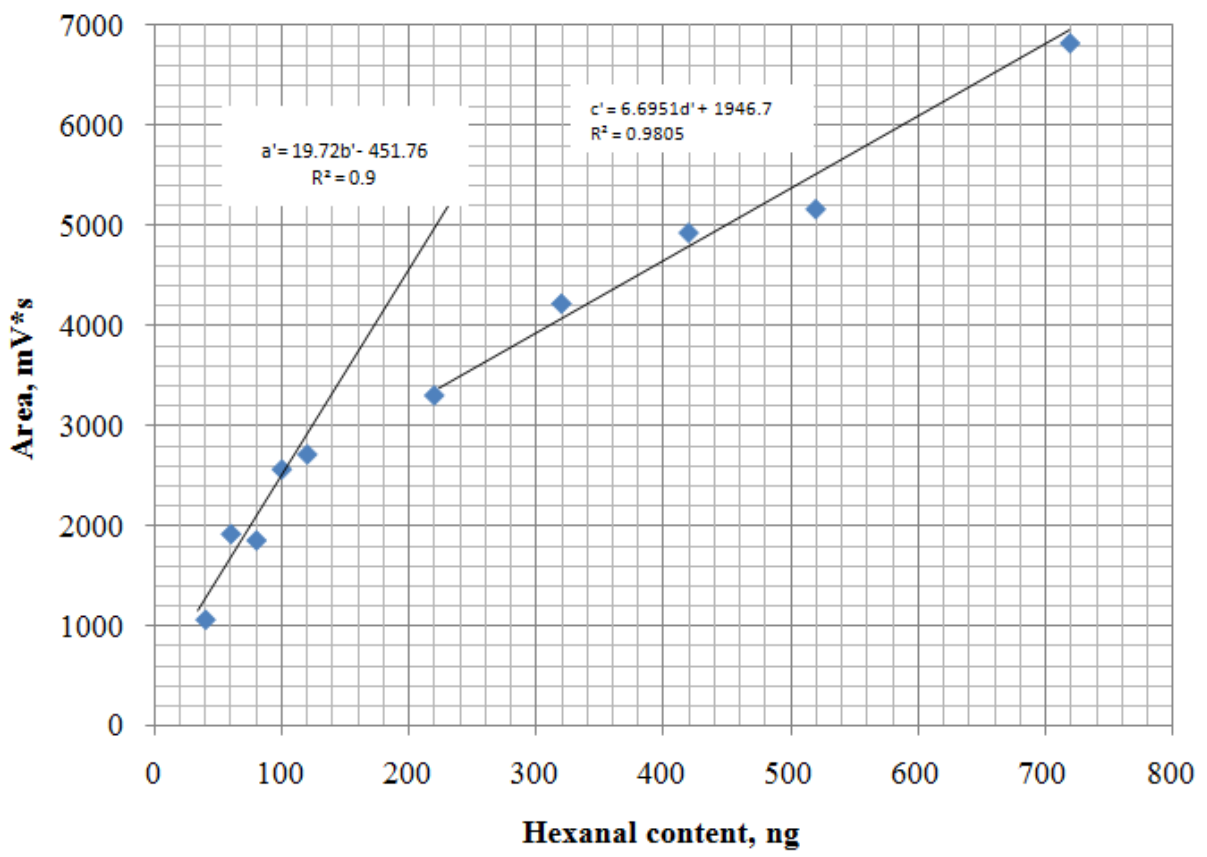

32 
36

37

38

39
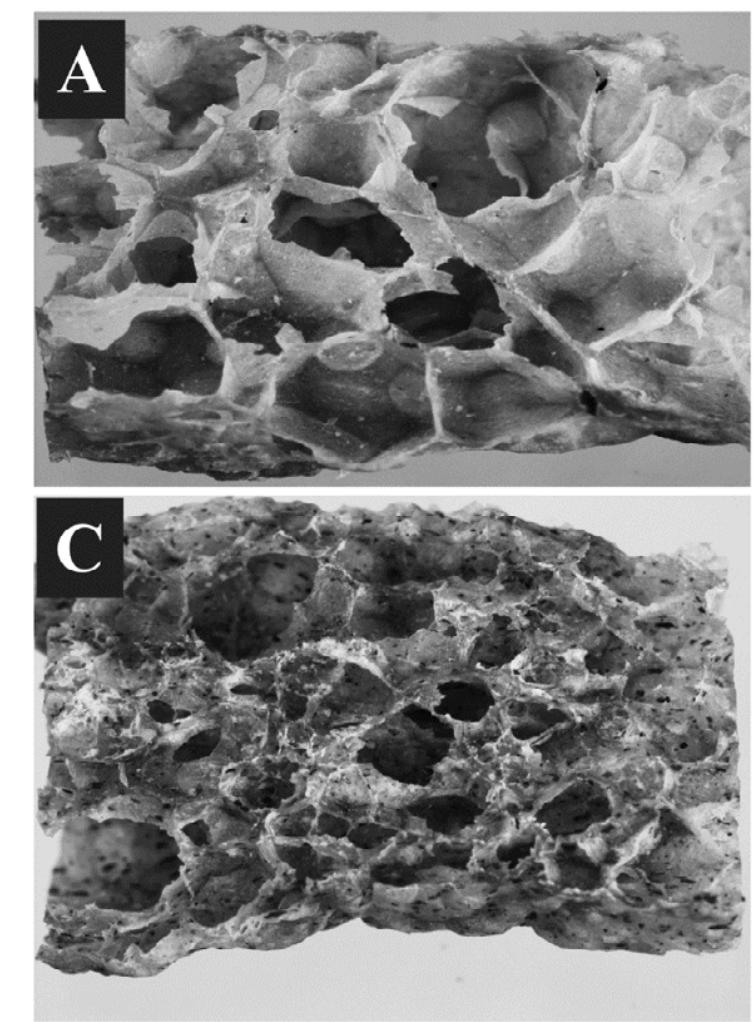

40

41

42

43

44

45

46 rpm, TEM $160^{\circ} \mathrm{C}$ )

Appendix D. Longitudinal section of corn-based extrudates containing 20\% amaranth (A), 20\%

quinoa (B), 20\% kañiwa (C) and 100\% corn (D). Samples from experiment 2 (WCM 15\%, SS 500
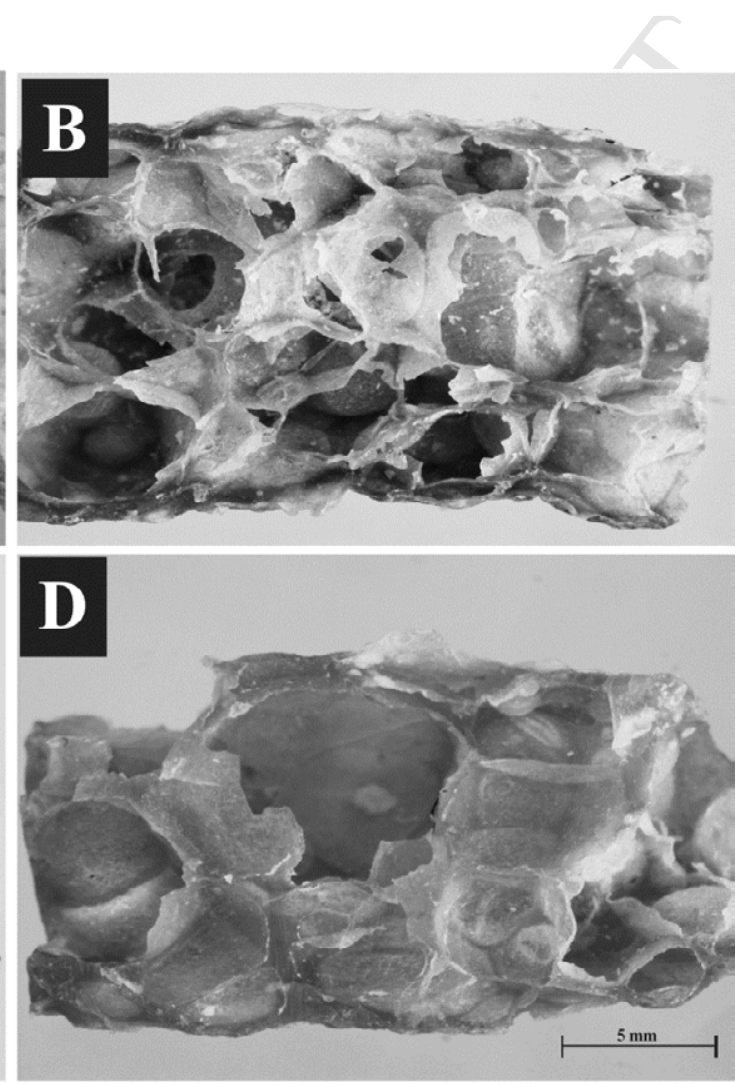